\title{
Regional Patterns of Sea Surface Temperature Change: A Source of Uncertainty in Future Projections of Precipitation and Atmospheric Circulation*
}

\author{
JIAN MA \\ Department of Meteorology, School of Ocean and Earth Science and Technology, University of Hawaii at Manoa, \\ Honolulu, Hawaii \\ SHANG-PING XIE \\ Department of Meteorology, and International Pacific Research Center, School of Ocean and Earth Science \\ and Technology, University of Hawaii at Manoa, Honolulu, Hawaii
}

(Manuscript received 22 May 2012, in final form 20 August 2012)

\begin{abstract}
Precipitation change in response to global warming has profound impacts on environment for life but is highly uncertain. Effects of sea surface temperature (SST) warming on the response of rainfall and atmospheric overturning circulation are investigated using Coupled Model Intercomparison Project simulations. The SST warming is decomposed into a spatially uniform SST increase (SUSI) and deviations from it. The SST pattern effect is found to be important in explaining both the multimodel ensemble mean distribution and intermodel variability of rainfall change over tropical oceans. In the ensemble mean, the annual rainfall change follows a "warmer-get-wetter" pattern, increasing where the SST warming exceeds the tropical mean, and vice versa. Two SST patterns stand out both in the ensemble mean and intermodel variability: an equatorial peak anchoring a local precipitation increase and a meridional dipole mode with increased rainfall and weakened trade winds over the warmer hemisphere. These two modes of intermodel variability in SST account for one-third of intermodel spread in rainfall projection.

The SST patterns can explain up to four-fifths of the intermodel variability in intensity changes of overturning circulations. SUSI causes both the Hadley and Walker circulations to slow down, as articulated by previous studies. The weakening of the Walker circulation is robust across models as the SST pattern effect is weak. The Hadley circulation change, by contrast, is significantly affected by SST warming patterns. As a result, near and south of the equator, the Hadley circulation strength change is weak in the multimodel ensemble mean and subject to large intermodel variability due to the differences in SST warming patterns.
\end{abstract}

\section{Introduction}

Human societies formed where fresh water was readily available. In many parts of the world, population increase and economic development have stretched water resources to near the breaking point, rendering societies ever more vulnerable to rainfall variability and change.

\footnotetext{
* International Pacific Research Center Contribution Number 908 and School of Ocean and Earth Science and Technology Contribution Number 8735 .

Corresponding author address: Jian Ma, Department of Meteorology, SOEST, University of Hawaii at Manoa, Honolulu, HI 96822.

E-mail: jianma@hawaii.edu
}

The looming global warming is almost certain to change the distribution of water resources (Zhang et al. 2007; Held et al. 2005; Seager et al. 2007), posing serious socioeconomic and security challenges that have profound impacts on the environment for life on Earth. Whereas the effects of the slow changes in precipitation patterns are obvious, their causes are illusive, uncertain, and poorly understood because of short observations and large natural variability.

The enormity of the problem calls for investigations into fundamental dynamics governing such changes, especially those in response to increasing greenhouse gases (GHGs). For this we analyze general circulation model (GCM) simulations (Table 1) in the World Climate Research Program's (WCRP's) Coupled Model Intercomparison Project (CMIP) phases 3 and 5 (Meehl 
TABLE 1. The WCRP CMIP3 models used in this study. Monthly output is directly adopted except for the listed variables converted

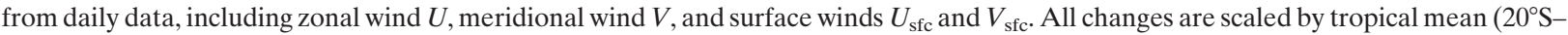
$\left.20^{\circ} \mathrm{N}\right)$ SST changes for the specific models.

\begin{tabular}{|c|c|c|c|c|}
\hline Model name & Country & $\begin{array}{l}\text { Atmospheric } \\
\text { resolution }\end{array}$ & $\begin{array}{l}\text { Oceanic } \\
\text { resolution }\end{array}$ & $\begin{array}{l}\text { Converted } \\
\text { variables }\end{array}$ \\
\hline $\begin{array}{l}\text { 1. Bjerknes Centre for Climate Research (BCCR) } \\
\text { Climate Model version } 2.0 \text { (BCM2.0) }\end{array}$ & Norway & T63 L31 & $2.4^{\circ} \times 2.4^{\circ}\left(0.8^{\circ}\right) \sigma 24$ & \\
\hline $\begin{array}{l}\text { 2. Canadian Centre for Climate Modelling and Analysis } \\
\text { (CCCma) Coupled General Circulation Model } \\
\text { version 3.1, T47 resolution (CGCM3.1 T47) }\end{array}$ & Canada & T47 L31 & $1.85^{\circ} \times 1.85^{\circ} \mathrm{L} 29$ & \\
\hline 3. CGCM version 3.1, T63 resolution (CGCM3.1 T63) & Canada & T63 L31 & $1.4^{\circ} \times 0.94^{\circ} \mathrm{L} 29$ & \\
\hline $\begin{array}{l}\text { 4. Centre National de Recherches Météorologiques } \\
\text { Coupled Global Climate Model, version } 3 \text { (CNRM } \\
\text { CM3) }\end{array}$ & France & T63 L45 & $2^{\circ} \times 0.5^{\circ} \mathrm{L} 31$ & \\
\hline $\begin{array}{l}\text { 5. Commonwealth Scientific and Industrial Research } \\
\text { Organisation (CSIRO) Mark version 3.0 (CSIRO } \\
\text { Mk3.0) }\end{array}$ & Australia & T63 L18 & $1.875^{\circ} \times 0.84^{\circ} \mathrm{L} 31$ & $U_{\mathrm{sfc}}, V_{\mathrm{sfc}}$ \\
\hline 6. CSIRO Mark version 3.5 (CSIRO Mk3.5) & Australia & T63 L18 & $1.875^{\circ} \times 0.84^{\circ} \mathrm{L} 31$ & \\
\hline $\begin{array}{l}\text { 7. Geophysical Fluid Dynamics Laboratory (GFDL) } \\
\text { Climate Model version } 2.0 \text { (GFDL CM2.0) }\end{array}$ & United States & $2.5^{\circ} \times 2^{\circ} \mathrm{L} 24$ & $1^{\circ} \times 1^{\circ}\left(1 / 3^{\circ}\right) \mathrm{L} 50$ & \\
\hline 8. GFDL Climate Model version 2.1 (GFDL CM2.1) & United States & $2.5^{\circ} \times 2^{\circ} \mathrm{L} 24$ & $1^{\circ} \times 1^{\circ}\left(1 / 3^{\circ}\right) \mathrm{L} 50$ & \\
\hline $\begin{array}{l}\text { 9. Goddard Institute for Space Studies (GISS) } \\
\text { Atmosphere-Ocean Model (GISS-AOM) }\end{array}$ & United States & $4^{\circ} \times 3^{\circ} \mathrm{L} 12$ & $4^{\circ} \times 3^{\circ} \mathrm{L} 16$ & \\
\hline 10. GISS Model E-H (GISS EH) & United States & $5^{\circ} \times 4^{\circ} \mathrm{L} 20$ & $2^{\circ} \times 2^{\circ} \mathrm{L} 16$ & \\
\hline 11. GISS Model E-R (GISS ER) & United States & $5^{\circ} \times 4^{\circ} \mathrm{L} 20$ & $5^{\circ} \times 4^{\circ} \mathrm{L} 13$ & \\
\hline $\begin{array}{l}\text { 12. Institute of Atmospheric Physics Flexible Global } \\
\text { Ocean-Atmosphere-Land System Model (IAP } \\
\text { FGOALS) }\end{array}$ & China & T42 L26 & $1^{\circ} \times 1^{\circ} \mathrm{L} 33$ & \\
\hline $\begin{array}{l}\text { 13. Istituto Nazionale di Geofisica e Vulcanologia } \\
\text { Model SXG (INGV SXG) }\end{array}$ & Italy & T106 L19 & $2^{\circ} \times 2^{\circ}\left(1^{\circ}\right) \mathrm{L} 31$ & $U_{\mathrm{sfc}}, V_{\mathrm{sfc}}$ \\
\hline $\begin{array}{l}\text { 14. Institute of Numerical Mathematics Coupled Model, } \\
\text { version 3.0 (INM-CM3.0) }\end{array}$ & Russia & $5^{\circ} \times 4^{\circ} \mathrm{L} 21$ & $2.5^{\circ} \times 2^{\circ} \mathrm{L} 33$ & \\
\hline $\begin{array}{l}\text { 15. L'Institut Pierre-Simon Laplace Coupled Model, } \\
\text { version } 4 \text { (IPSL CM4) }\end{array}$ & France & $2.5^{\circ} \times 3.75^{\circ} \mathrm{L} 19$ & $2^{\circ} \times 1^{\circ} \mathrm{L} 31$ & \\
\hline $\begin{array}{l}\text { 16. Model for Interdisciplinary Research on Climate 3.2, } \\
\text { high-resolution [MIROC3.1(hires)] }\end{array}$ & Japan & T106 L56 & $0.28^{\circ} \times 0.19^{\circ} \mathrm{L} 47$ & \\
\hline 17. MIROC3.2, medium resolution [MIROC3.1(medres)] & Japan & T42 L20 & $1.4^{\circ} \times 0.5^{\circ} \mathrm{L} 43$ & \\
\hline $\begin{array}{l}\text { 18. ECHAM and the global Hamburg Ocean Primitive } \\
\text { Equation [Meteorological Institute of the University } \\
\text { of Bonn (MIUB) ECHO-G] }\end{array}$ & $\begin{array}{l}\text { Germany/South } \\
\text { Korea }\end{array}$ & T30 L19 & $2.8^{\circ} \times 2.8^{\circ} \mathrm{L} 20$ & $T_{a}, U, V, q$ \\
\hline 19. Max Planck Institute ECHAM5 (MPI ECHAM5) & Germany & T63 L31 & $1.5^{\circ} \times 1.5^{\circ} \mathrm{L} 40$ & \\
\hline $\begin{array}{l}\text { 20. Meteorological Research Institute Coupled General } \\
\text { Circulation Model, version 2.3 (MRI CGCM2.3) }\end{array}$ & Japan & T42 L30 & $2.5^{\circ} \times 0.5^{\circ} \mathrm{L} 23$ & \\
\hline $\begin{array}{l}\text { 21. Third climate configuration of the Met Office Unified } \\
\text { Model (UKMO HadCM3) }\end{array}$ & United Kingdom & $3.75^{\circ} \times 2.5^{\circ} \mathrm{L} 19$ & $1.25^{\circ} \times 1.25^{\circ} \mathrm{L} 30$ & \\
\hline $\begin{array}{l}\text { 22. Met Office Hadley Centre Global Environmental } \\
\text { Model version } 1 \text { (UKMO HadGEM1) }\end{array}$ & United Kingdom & $1.875^{\circ} \times 1.25^{\circ} \mathrm{L} 38$ & $1^{\circ} \times 1^{\circ}\left(1 / 3^{\circ}\right) \mathrm{L} 40$ & \\
\hline
\end{tabular}

et al. 2007). In model projections for climate change during the twenty-first century, global-mean rainfall increases at a much slower rate $(2 \%-3 \%$ per degree of surface warming) (Held and Soden 2006) than atmospheric moisture content $\left(7 \% \mathrm{~K}^{-1}\right)$. This difference implies a slowing down of tropical circulation (Vecchi and Soden 2007a), a prediction confirmed for the Walker cell (Vecchi et al. 2006), although satellite-based microwave measurements question this slower increase rate (Wentz et al. 2007). Recent observational studies suggest a strengthening of the Pacific Walker circulation during the last two decades (Sohn and Park 2010; Merrifield 2011), which may be associated with natural variability, with SST warming in the central-western and cooling in the eastern Pacific. The GHG-induced slowdown of tropical circulation can also be interpreted as due to the mean advection of stratification change (MASC) effect (Ma et al. 2012), which causes anomalous cold (warm) advection in climatological ascending (descending) regions, as a result of increased dry stability. 
TABLE 2. Ensemble means of spatial mean $\left(M_{x, y}\right)$ and variability $\left(\sigma_{x, y}\right)$ of changes in air temperature at $2 \mathrm{~m}$ and precipitation in the 22 CMIP3 models. Changes are defined as the annual mean of 2091-2100 minus that of 2001-10, normalized by the tropical mean SST warming. The calculations are limited to nearly ice-free regions $\left(60^{\circ} \mathrm{S}-60^{\circ} \mathrm{N}\right)$.

\begin{tabular}{ccccccccc}
\hline \hline & \multicolumn{3}{c}{$\begin{array}{c}\text { Air temperature } \\
\text { at } 2 \mathrm{~m}(\mathrm{~K})\end{array}$} & & & \multicolumn{3}{c}{$\begin{array}{c}\text { Precipitation } \\
\left(\mathrm{mm} \text { month }^{-1}\right)\end{array}$} \\
\cline { 2 - 4 } \cline { 7 - 9 }$\left(60^{\circ} \mathrm{S}-60^{\circ} \mathrm{N}\right)$ & Global & Ocean & Land & & Global & Ocean & Land \\
\hline$M_{x, y}$ & 1.16 & 0.98 & 1.53 & & 1.43 & 1.70 & 0.86 \\
$\sigma_{x, y}$ & 0.45 & 0.34 & 0.39 & & 6.95 & 7.43 & 5.56 \\
\hline
\end{tabular}

However, the difference in the robustness of the Walker (Vecchi and Soden 2007a) and Hadley (Ma et al. 2012) circulation changes calls for research into the source of uncertainty.

Precipitation change is highly uneven in space. Its spatial variability is greater than the global mean by a factor of 4 (Table 2). Research into patterns of precipitation change starts from a "wet-get-wetter" view. This predicts that rainfall increases in the core of existing rainy regions and decreases on their margins and in current dry areas, based on an argument of intensified moisture advection due to atmospheric warming (Neelin et al. 2003; Chou and Neelin 2004; Chou et al. 2009; Held and Soden 2006; Seager et al. 2010). A spatially uniform sea surface temperature (SST) increase (SUSI) is implicitly assumed, neglecting spatial variations in surface warming and the associated wind change.

The SST warming displays considerable variations in space (Xie et al. 2010) with robust and coherent seasonal variability (Sobel and Camargo 2011). A "warmerget-wetter" paradigm emerges, casting the relative SST warming $T^{*}$, defined as deviations from the tropical mean SST increase, as important for regional changes in tropical cyclone activity (Vecchi and Soden 2007b), precipitation (Xie et al. 2010; Sobel and Camargo 2011), and atmospheric circulation (Ma et al. 2012; Gastineau et al. 2009). Upper tropospheric warming is nearly spatially uniform in the tropics because of fast wave actions (Sobel and Bretherton 2000; Sobel et al. 2002), so convective instability is largely determined by spatial variations in SST warming and related low-level moisture change (Johnson and Xie 2010). Complementary analyses based on moist energy (Chou et al. 2009) and moisture (Seager et al. 2010) budgets show the importance of atmospheric circulation for precipitation change.

This SST pattern control on rainfall reorganization can be illustrated by a comparison of two CMIP3 model simulations forced with the Intergovernmental Panel on Climate Change (IPCC) Special Report on Emissions Scenarios (SRES) scenario A1B. Figure 1 shows that oceanic rainfall changes are quite different between the Geophysical Fluid Dynamics Laboratory (GFDL) CM2.0 and the Met Office (UKMO) HadCM3 (note that all CMIP3 model names are expanded in Table 1). Over the tropical Pacific, the CM2.0 features a pronounced increase in rainfall on the equator (especially the western side) and drastic reduction on the sides. By contrast, the HadCM3 rainfall change is characterized by an interhemispheric asymmetry with increased rainfall north of the equator. Spatial correlation $r$ in tropical $\left(20^{\circ} \mathrm{S}-20^{\circ} \mathrm{N}\right)$ rainfall change between the two models is only -0.03 . Remarkably, the disparity in rainfall response to the A1B scenario can be explained by the intermodel difference in SST warming (Fig. 1c). Positive SST difference (CM2.0 minus HadCM3) is found collocated with enhanced rainfall in all three tropical oceans. Indeed, the spatial correlation between SST and rainfall differences reaches 0.56 , illustrating the importance of SST warming pattern.

The present study investigates the effects of SST warming pattern on changes in tropical precipitation and circulation. It extends previous studies by analyzing a large number of coupled model simulations in the CMIP database and by using atmospheric SUSI simulations to isolate SST pattern effects. We show that the warmer-get-wetter mechanism accounts for much of the spatial variations in tropical rainfall response to $\mathrm{GHG}$ forcing as represented by the multimodel ensemble mean. As Fig. 1 illustrates, rainfall projection varies greatly among models, and the causes of this uncertainty have not been fully explored. We show that the differences in spatial patterns of SST warming are an important source of intermodel diversity in tropical rainfall projection, highlighting the need to study SST warming pattern as an ocean-atmosphere interaction problem. Finally, we examine the response of atmospheric overturning circulation to global warming and again identify SST pattern as an important cause of variability among models, especially for the Hadley circulation change.

The rest of the paper is arranged as follows. Section 2 describes the data and methods. Section 3 examines the relationship among change patterns of SST, precipitation, and atmospheric circulation in the CMIP3 ensemble mean. Section 4 investigates the SST effect on the intermodel variations in precipitation change. Influences of SST warming on overturning circulation changes are discussed in section 5. Section 6 gives conclusions with discussion.

\section{Data and methods}

This study uses CMIP3 and CMIP5 output, and atmospheric GCM (AGCM) experiments (Table 3) to 


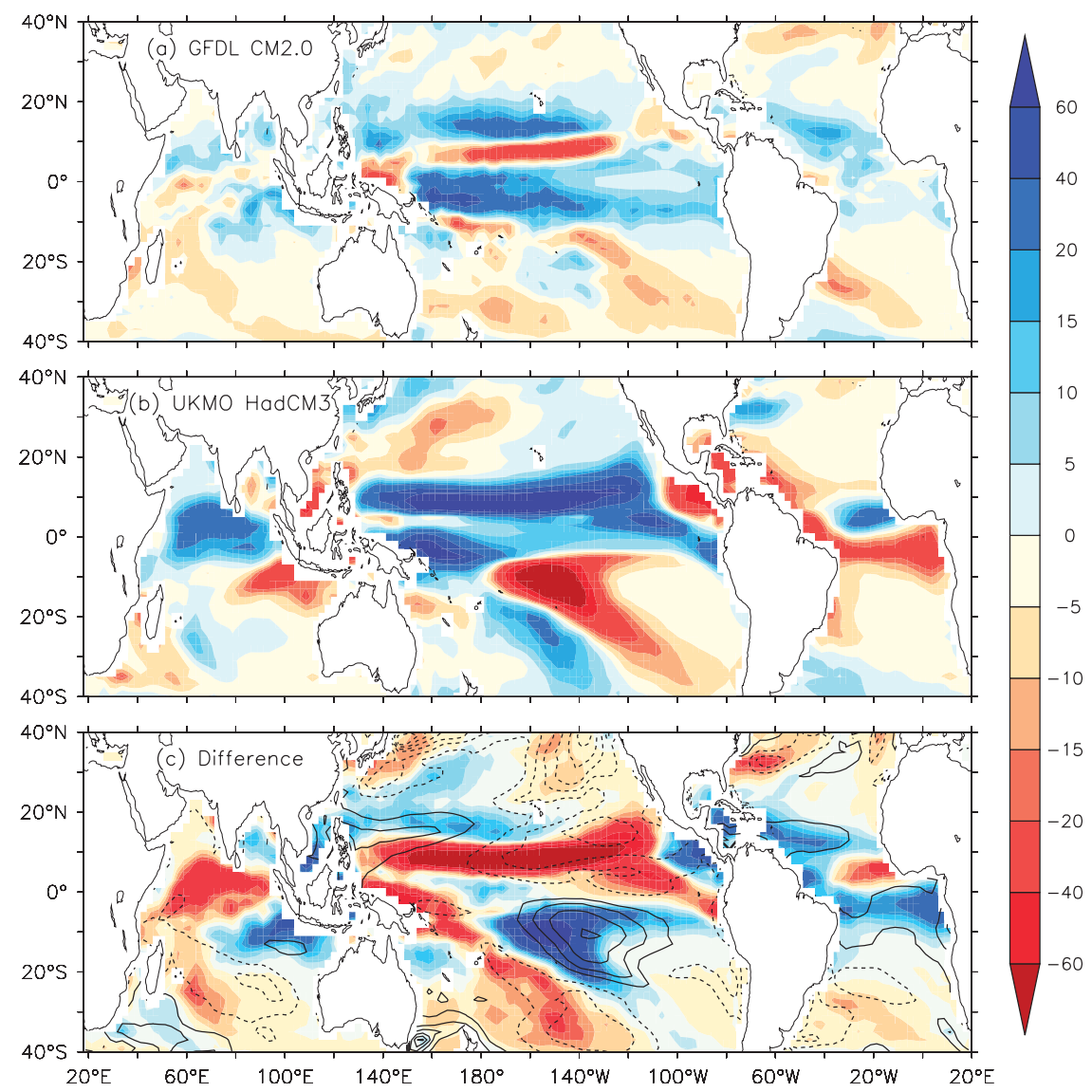

FIG. 1. Comparison of annual mean rainfall changes (color shading, $\mathrm{mm} \mathrm{month}^{-1}$ ) between (a) GFDL CM2.0 and (b) HadCM3 in the CMIP3 ensemble under the SRES A1B emission scenario. (c) Their difference along SST difference in contours [contour interval $(\mathrm{CI}): 0.2 \mathrm{~K}$; $0 \mathrm{~K}$ contour omitted].

investigate the response of precipitation and atmospheric circulation to global warming.

\section{a. CMIP3 models}

We analyze CMIP3 model simulations (Table 1 ) forced with the IPCC SRES A1B scenario representing the emission of a few climatically important trace gases (e.g., carbon dioxide and ozone). Based on certain socioeconomic development paths for the twenty-first century, this scenario projects a rough doubling of atmospheric $\mathrm{CO}_{2}$ for the century as well as a recovery of the Southern Hemisphere "ozone hole" by approximately 2050. (Details of the models can be found at http://www-pcmdi.llnl.gov/ ipcc/model_documentation/ipcc_model_documentation. php, and the output at https://esg.llnl.gov:8443/index. jsp.) A total of 22 models are included with one realization for each model. Monthly output is used. When monthly means are unavailable, we either compute from daily output or convert from other variables. See details in Table 1.
To extract robust anthropogenic global warming signals, changes are computed for the twenty-first century between two 10-yr periods: 2001-10 and 2091-2100. Then, they are normalized by the tropical $\left(20^{\circ} \mathrm{S}-20^{\circ} \mathrm{N}\right)$ mean SST warming in each model before calculating the ensemble averages and the deviations from the ensemble mean.

The SUSI experiments advocated by the Cloud Feedback Model Intercomparison Project (CFMIP; Ringer et al. 2006) are used for zonal mean comparisons with the A1B simulations [only GFDL AM2.1 (i.e. the atmospheric component of CM2.1), MPI ECHAM5, and NCAR CAM3.1 are available].

\section{b. CMIP5 data}

The CMIP5 output under the representative concentration pathway 4.5 (RCP4.5) is available for 22 models. Our preliminary analyses of RCP4.5 data generally support the A1B results of CMIP3 to be presented here. We only include a brief discussion on 
TABLE 3. Data and experiments analyzed in this study.

\begin{tabular}{|c|c|c|}
\hline Model & Experiment & Description \\
\hline \multirow[t]{2}{*}{ CMIP3 } & A1B & $\begin{array}{l}\text { Changes are calculated as } \\
2091-2100 \text { minus } 2001-10\end{array}$ \\
\hline & SUSI & $\begin{array}{l}\text { Spatially uniform SST warming } \\
\text { by } 2 \mathrm{~K}\end{array}$ \\
\hline \multirow[t]{4}{*}{ CMIP5-CFMIP2 } & $\begin{array}{l}\text { Coupled } \\
\text { models }\end{array}$ & $\begin{array}{l}\mathrm{CO}_{2} \text { increases at } 1 \% \mathrm{yr}^{-1} \\
\text { until quadrupling } \\
(\sim 140 \mathrm{yr})\end{array}$ \\
\hline & RAD & $\begin{array}{l}\text { Quadrupling } \mathrm{CO}_{2} \text { while holding } \\
\text { SST at current climate }\end{array}$ \\
\hline & SUSI & $\begin{array}{l}\text { SST is spatially uniformly } \\
\text { warmed by } 4 \mathrm{~K}\end{array}$ \\
\hline & $T^{*}$ & $\begin{array}{l}\text { Calculated as residual [Coupled } \\
\text { models }-(\mathrm{RAD}+\mathrm{SUSI})]\end{array}$ \\
\hline \multirow[t]{5}{*}{ AGCM } & CAM_A1B & $\begin{array}{l}\text { SST increases as the CMIP3 } \\
\text { ensemble mean }\end{array}$ \\
\hline & CAM_SUSI & $\begin{array}{l}\text { SST is spatially uniformly } \\
\text { warmed by } 2 \mathrm{~K}\end{array}$ \\
\hline & CAM_T* & $\begin{array}{l}\text { Only spatial patterns of SST } \\
\text { change are applied }\end{array}$ \\
\hline & CAM_NEP & $\begin{array}{l}\text { Equatorial peak of } T^{*} \text { is } \\
\text { eliminated }\end{array}$ \\
\hline & CAM_EP & $\begin{array}{l}\text { Equatorial peak effect only } \\
\text { (CAM_T* - CAM_NEP) }\end{array}$ \\
\hline
\end{tabular}

RCP4.5 results, as the detailed comparison will be reported elsewhere.

We use the CFMIP2 simulations as part of CMIP5 (Table 3) to isolate the mechanisms for changes of the overturning circulations:

- Coupled models: $\mathrm{CO}_{2}$ concentration increases at $1 \% \mathrm{yr}^{-1}$ until quadrupling ( $\left.140 \mathrm{yr}\right)$;

- Direct radiative (RAD) (CFMIP2): Quadrupling $\mathrm{CO}_{2}$ concentration while holding SST at the current climate;

- SUSI (CFMIP2): SST is spatially uniformly warmed by $4 \mathrm{~K}$ (Cess et al. 1990);

- $T^{*}$ : Effect of SST warming patterns is calculated as residual [coupled models - (RAD + SUSI)].

Note that some of the SST patterns are due to the great ocean inertia, such as the reduced warming over the Southern Ocean and subpolar North Atlantic (Manabe and Stouffer 1988). All results are normalized by their tropical $\left(20^{\circ} \mathrm{S}-20^{\circ} \mathrm{N}\right)$ mean SST increases. Currently, five models are available: the Canadian Earth System Model version 2 with atmospheric model version 4 (CanESM2/AM4); the Centre National de Recherches Météorologiques Coupled Global Climate Model, version 5 (CNRM-CM5); the Hadley Centre Global Environmental Model versions 2-ES and 2-A (HadGEM2ES/-A); L'Institut Pierre-Simon Laplace Coupled Model, version 5a, low resolution (IPSL-CM5A-LR); and the Model for Interdisciplinary Research on Climate, version 5 (MIROC5).

\section{c. AGCM simulations}

To test the atmospheric response to multiple components of the SST warming, we perform a sensitivity study using the National Center for Atmospheric Research (NCAR) Community Atmosphere Model (CAM), version 3.1. CAM is a global AGCM developed by the climate research communities in collaboration with NCAR (Collins et al. 2006). Coupled with a land model and a thermodynamic sea ice model, it is suitable for examining the response of the atmospheric circulation and rainfall to changes in SST.

We run the model for 20 years with triangular truncation at T42 (equivalent grid spacing of $2.88^{\circ}$ ) and 26 vertical levels. The CAM experiments are forced with the observed monthly mean SST climatology plus changes (except the control run) derived from the CMIP3 ensemble and annual mean SST warming, which is decomposed into SUSI and patterns. Specifically, they include the following cases (Table 3):

- CAM_A1B: SST increases as the CMIP3 ensemble mean;

- CAM_SUSI: SST is spatially uniformly warmed by $2 \mathrm{~K}$;

- CAM_T*: Only spatial patterns of SST change (i.e., $\left.T^{*}\right)$ are applied, defined as the deviations of the CMIP3 warming from the tropical $\left(20^{\circ} \mathrm{S}-20^{\circ} \mathrm{N}\right)$ mean, equivalent to CAM_A1B minus CAM_SUSI;

- CAM_NEP: The equatorial peak of $T^{*}$ (Fig. 2) is eliminated by applying a Gaussian weight in the meridional direction;

- CAM_EP: Equatorial peak effect only, calculated as CAM_ $T^{*}$ minus CAM_NEP.

\section{d. Moisture budget analysis}

We perform a moisture budget analysis to decompose the atmospheric dynamic and thermodynamic contributions to rainfall change over ocean (Seager et al. 2010). Once the atmospheric moisture equation is vertically integrated, one obtains

$$
\overline{P-E}=-\langle\nabla \cdot(\overline{\mathbf{V}} \bar{q})\rangle+\text { Eddy },
$$

where $P$ is precipitation, $E$ is evaporation, the angle brackets $\langle\cdot\rangle$ represent column mass integration throughout the troposphere (approximated as $200-1000 \mathrm{hPa}$ ), and the overbar denotes the monthly average. The $\mathbf{V}$ denotes three-dimensional atmospheric velocity, but here we use two-dimensional fields to include more models, assuming that pressure velocity is small at the tropopause and ocean surface. The eddy term is due to submonthly variability and calculated as residual. 

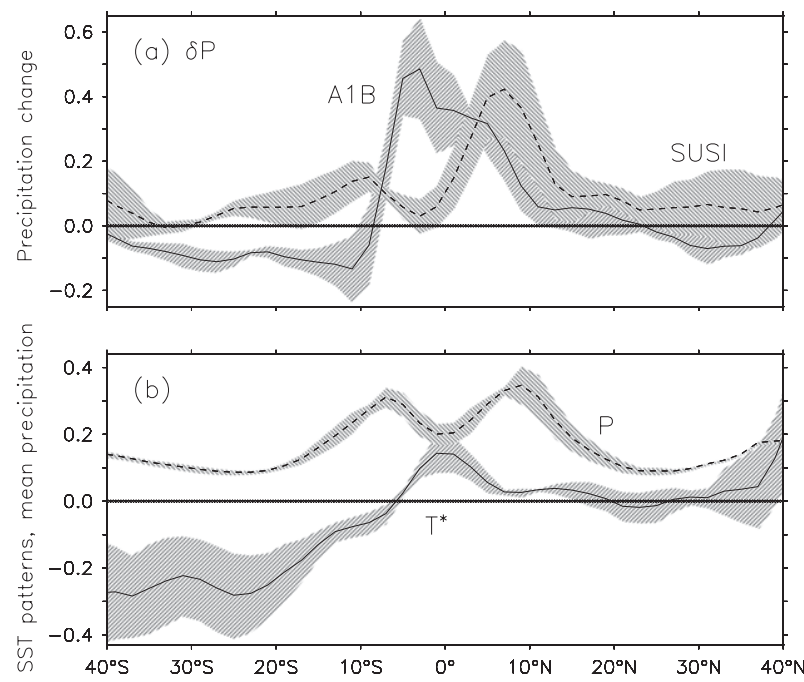

FIG. 2. Comparison of annual and zonal mean oceanic rainfall changes between A1B and SUSI simulations, in relation to the climatological precipitation and relative SST warming. The ensemble means are shown for (a) A1B (solid) and SUSI (dashed) rainfall changes $\delta P\left(\mathrm{~mm} \mathrm{day}^{-1}\right)$ normalized by tropical $\left(20^{\circ} \mathrm{S}-\right.$ $20^{\circ} \mathrm{N}$ )-mean SST warming, and (b) normalized A1B SST warming patterns $T^{*}$ (K; solid) and rainfall climatology $P\left(20 \mathrm{~mm} \mathrm{day}^{-1}\right.$; dashed), with intermodel spreads (ensemble mean \pm 1 standard deviation) marked by the shaded ranges. The model ensemble includes GFDL CM2.1, MPI ECHAM5, and NCAR CCSM3.

In global warming, the perturbation of $P-E$ can be linearly decomposed as

$\delta(\overline{P-E})=-\langle\nabla \cdot(\delta \overline{\mathbf{V}} \bar{q})\rangle-\langle\nabla \cdot(\overline{\mathbf{V}} \delta \bar{q})\rangle+\delta$ Eddy,

where the first term on the right-hand side represents the contribution of circulation change (dynamic effect) and the second term represents moisture content change (thermodynamic effect).

\section{e. Statistical methods}

Empirical orthogonal function (EOF) and singular value decomposition (SVD) analyses are applied to the CMIP3 ensemble to investigate the intermodel variability of SST change patterns and its contributions to changes in other variables.

\section{Ensemble mean change patterns}

This section examines tropical rainfall change under global warming and relates it to SST warming pattern. We start with an analysis of the CMIP3 ensemble mean, followed with a water vapor budget and AGCM experiments.

\section{a. SST, rainfall, and surface winds}

To highlight the effect of spatial variations in SST warming, we compare the CMIP3 model projections under the SRES A1B emission scenario and simulations with their atmospheric components in response to a SUSI of $2 \mathrm{~K}$, with the latter available through the CFMIP (Ringer et al. 2006). Figure 2 presents the zonal mean rainfall changes over ocean in these model ensembles, with climatological precipitation and SST change for reference. Rainfall change in SUSI runs (Fig. 2a) resembles the climatology (Fig. 2b). They share an equatorial minimum sandwiched by double peaks on either side, with $r=0.67$ in $20^{\circ} \mathrm{S}-20^{\circ} \mathrm{N}$. A maximum of intermodel variations anchoring the Northern Hemispheric peak appears consistently in both fields. This relationship in SUSI is consistent with the wet-getwetter mechanism (Xie et al. 2010).

The SST change develops patterns in space, here measured by $T^{*}$, the deviations of SST warming from its tropical $\left(20^{\circ} \mathrm{S}-20^{\circ} \mathrm{N}\right)$ mean increase. In the zonal mean (Fig. 2b), major features of these patterns include an equatorial peak (Liu et al. 2005) and south-to-north gradients (Xie et al. 2010). The mean rainfall change of the A1B ensemble (Fig. 2a) shows little correlation with SUSI $(r=0.18)$. Instead of an equatorial minimum in SUSI, A1B precipitation features a broad equatorial increase with some intermodel spread, apparently forced by the equatorial maximum in $T^{*}$, which also shows considerable spread. The subtropical reduction in A1B precipitation seems to fit the "dry-get-drier" pattern but is actually associated with reduced SST warming $\left(T^{*}<\right.$ $0)$, especially in the Southern Hemisphere. In A1B simulations, the ensemble mean precipitation change and relative SST warming are highly correlated at $r=$ 0.80 . This relation illustrates the dominance of the warmer-get-wetter mechanism in the coupled models. Oceanic feedback due to changes in surface heat flux is discussed in Chou et al. (2009).

Figures $3 \mathrm{a}$ and $3 \mathrm{~b}$ compare percentage precipitation change with relative SST warming in the 22 CMIP3 models under A1B scenario (Table 1). A clear correlation $(r=0.68)$ in space emerges in the ensemble mean, with increasing $\delta P / P$ generally collocated with positive $T^{*}$, and vice versa. In particular, the equatorial maximum in $T^{*}$ anchors a large precipitation increase in the equatorial Pacific; whereas precipitation generally decreases in the subtropical Southern Hemisphere where SST warming is subdued $\left(T^{*}<0\right)$. The reduced SST warming is associated with the intensified southeasterly trade winds (Fig. 3c), suggestive of windevaporation-SST (WES) feedback (Xie and Philander 1994). Reduced warming and suppressed rainfall are also found over the subtropical North Atlantic, a result of enhanced evaporative damping rate (Leloup and Clement 2009) and ocean circulation change (Xie et al. 2010). 


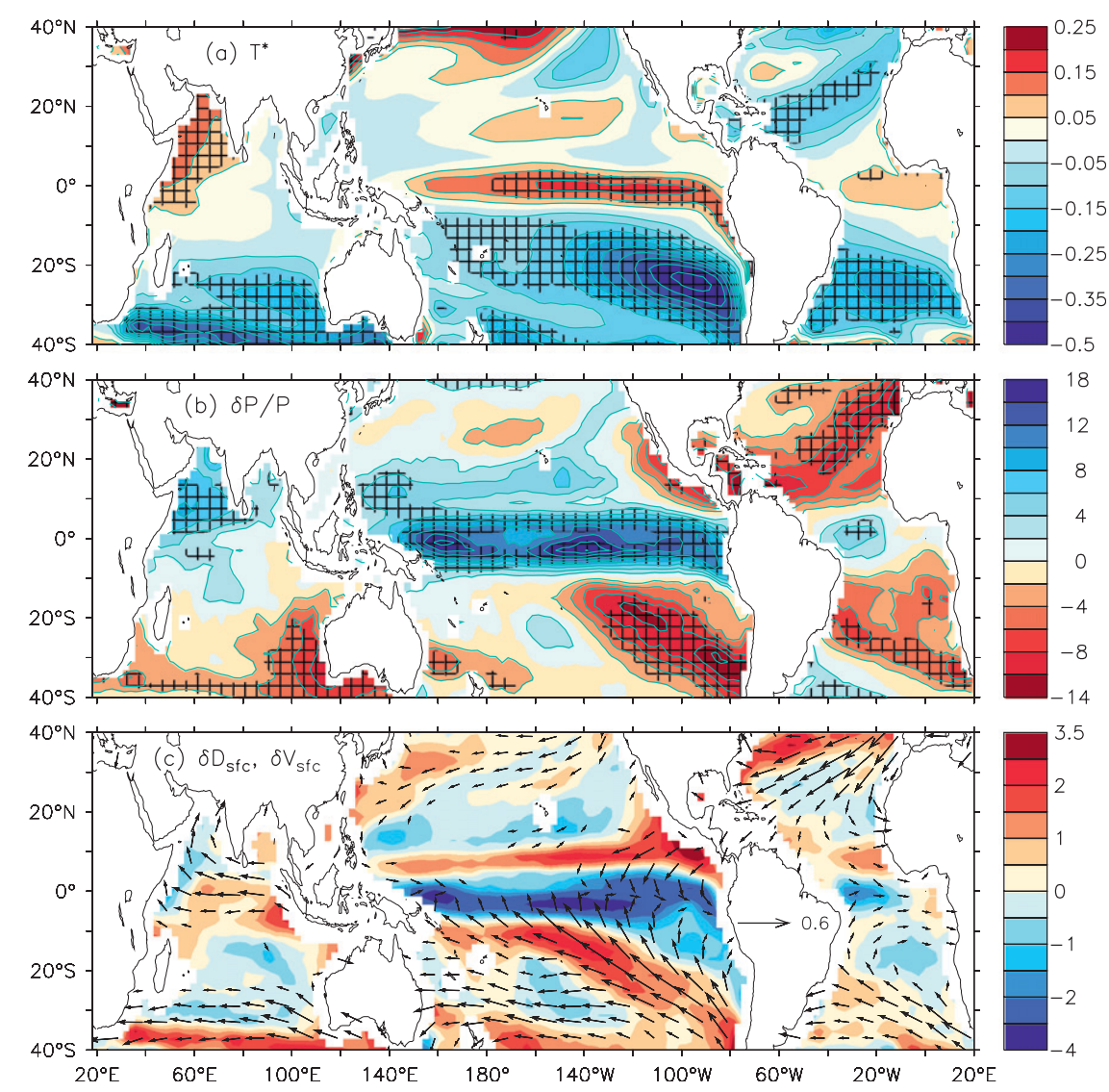

FIG. 3. Relationship between annual mean rainfall and SST change patterns projected by the 22 CMIP3 models under the SRES A1B emission scenario. The ensemble means (color shading) of (a) relative SST warming $T^{*}(\mathrm{~K})$ and (b) percentage rainfall change $\delta P / P(\%)$, along with robustness defined as the ratio of the ensemble mean (absolute value) to intermodel spread (values $>0.75$ mapped with grid). (c) The ensemble-mean change in surface wind (vectors, $\mathrm{m} \mathrm{s}^{-1}$ ) and divergence (color shading, $10^{-7} \mathrm{~s}^{-1}$ ).

SST change patterns are robust for the equatorial peak and Southern Hemispheric minima (Fig. 3a). The robustness of rainfall change there (Fig. $3 \mathrm{~b}$ ) is an SST effect. Moderate uncertainty in rainfall change for the central equatorial Pacific may be due to differences in the model physics/coupling scheme (e.g., the intensity of the climatological equatorial cold tongue).

A strong spatial correlation between $\delta P / P$ and $T^{*}$ in the A1B ensemble mean suggests an empirical relation (Fig. 4)

$$
\delta P / P=\alpha T^{*}+\beta \bar{T},
$$

where $\alpha=44 \% \mathrm{~K}^{-1}, \beta=2 \% \mathrm{~K}^{-1}$, and $\bar{T}=1 \mathrm{~K} \mathrm{~K}^{-1}$ (the tropical mean warming normalized by itself). In SUSI, $T^{*}=0$ and $\delta P$ is proportional to $P$, representing the wet-get-wetter mechanism. Also, $\beta$ measures the percentage increase in the tropical average rainfall due to SUSI and direct radiative effects. In A1B, $T^{*}$ is only a fraction of the tropical mean SST warming (Table 2), but its effect on rainfall change [the first term on the right-hand side of Eq. (3)] is an order of magnitude greater than the second term (Fig. 4). In Table 2, a common rule stands out for both ocean and land. The standard deviation of 2-m air temperature warming is only a fraction of its global mean, whereas the spatial variability in rainfall change is 4 times larger than the mean. The mean land warming is 1.5 times that of the ocean warming, but the spatial variability is similar in magnitude. For precipitation, the mean and variability are both smaller over land than over ocean.

The Clausius-Clapeyron equation predicts that the atmospheric moisture content increases at a rate of $\alpha_{0}=$ $7 \% \mathrm{~K}^{-1}$ (Held and Soden 2006). The fact that $\alpha \gg$ $\alpha_{0}$ indicates that besides a weak contribution from spatial variation of moisture increase, the circulation change is important for regional precipitation change. Figure $3 \mathrm{c}$ shows that the SST pattern dominates the sea 


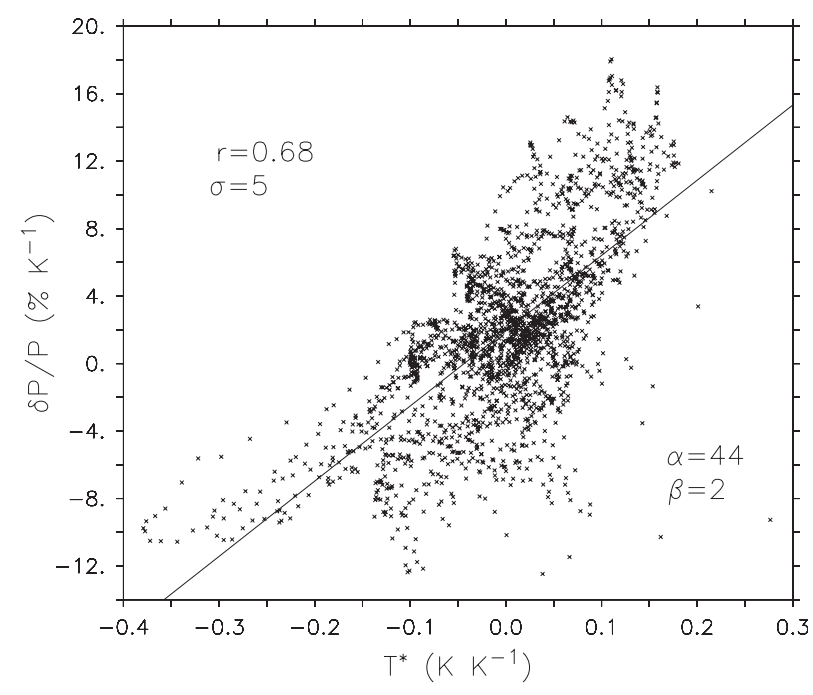

FIG. 4. Scatterplot between the percentage change of tropical $\left(20^{\circ} \mathrm{S}-20^{\circ} \mathrm{N}\right)$ rainfall and relative SST warming in the ensemble mean of CMIP3 models under the A1B scenario. Also marked are the spatial correlation $(r)$, standard deviation $(\sigma)$ of rainfall changes, growth rate $(\alpha)$, and intercept $(\beta)$ of the linear fit.

surface wind change and moisture convergence. Indeed, convergence is generally found where precipitation increases and $T^{*}>0$, indicative of a strong positive feedback between circulation and convection that is commonly seen in the tropics (Back and Bretherton 2006).

For individual models (Fig. 5), $\alpha$ varies in the range of $10 \%-70 \% \mathrm{~K}^{-1}$, with a right-skewed distribution, and $\beta$ in the range of $-1 \%$ to $5 \% \mathrm{~K}^{-1}$. Not surprisingly, models with large $\alpha$ feature a high correlation (i.e., $r$ ) between $\delta P / P$ and $T^{*}$ (Fig. 5d). The intermodel correlation is 0.62 between $r$ and $\alpha$.

\section{b. Moisture budget analysis}

A moisture budget analysis [Eq. (2)] helps identify whether the SST pattern control on regional precipitation is through spatial variations in water vapor increase or associated with atmospheric circulation change by quantifying the relative importance of the atmospheric dynamic and thermodynamic contributions to $\delta(\overline{P-E})$. Figure 6 illustrates the CMIP3 ensemblemean results over ocean. The $\overline{P-E}$ change (Fig. 6a) is well correlated in space with the contribution by circulation change (Fig. 6b), with $r=0.73 \pm 0.10$ in the multimodel ensemble. Especially, the rainfall enhancement in the equatorial Pacific and reduction in the southeastern Pacific are due to circulation change associated with SST patterns. While the moisture increase (Fig. 6c) produces the wet-get-wetter pattern, its correlation with $P-E$ is quite low $(r=0.30 \pm 0.17)$. This confirms that over ocean, although $T^{*}$ is only a fraction of the tropical mean SST warming (Table 2), the near-surface atmospheric circulation change induced by SST patterns dominates the regional precipitation response to global warming. The eddy contribution (Fig. 6d) shows a clear poleward expansion of the Hadley cell in the Pacific and Atlantic Oceans.

Both the SUSI and SST pattern effects involve thermodynamic and dynamic processes. In SUSI, the thermodynamic effect dominates, but the dynamic effect associated with the weakening of the tropical circulation (Held and Soden 2006) also contributes, particularly in magnitude. With SST patterns, the dynamic effect determines the spatial pattern of precipitation change, but the thermodynamic effect also contributes to the magnitude. To first order, the thermodynamic component approximately represents the wet-get-wetter view (Fig. 6c), while the dynamic component expresses the warmerget-wetter view (Fig. 6b), especially in spatial pattern.

\section{c. AGCM experiments}

We perform AGCM experiments to test how different components of SST warming, including the SUSI and spatial pattern, influence the atmospheric circulation and regional rainfall. Although implied to be the cause of atmospheric changes in this type of experiments, SST anomalies are determined by ocean-atmosphere interactions, which need further investigations ( $\mathrm{Lu}$ and Zhao 2012).

Figure 7 evaluates the ability of CAM3.1 to simulate the ensemble mean change in the CMIP3 models. With $r=0.62$ in $20^{\circ} \mathrm{S}-20^{\circ} \mathrm{N}$, the CAM_A1B experiment (Fig. 7a) can reproduce the regional precipitation change in Fig. $3 \mathrm{~b}$ quite well, including the strong equatorial enhancement and the reduction in the southeastern Pacific, subtropical Atlantic, and Indian Ocean. Surface wind change is also well simulated, with the enhanced southeasterly trades in the southeastern Pacific and weakening of the Walker circulation.

The CAM_SUSI experiment (Fig. 7b) shows that the tropical mean SST warming contributes to the rainfall reduction in the northeastern Pacific and the Mediterranean Sea. Besides, the SUSI causes cyclonic circulation in major subtropical ocean basins, which corresponds to the slowdown of surface winds. Specifically, this is consistent with the weakening of the Walker circulation.

Figures $7 \mathrm{c}$ and $7 \mathrm{~d}$ compare the effect of $T^{*}$ evaluated with different methods as the difference between the CAM_A1B and CAM_SUSI runs, and the atmospheric response to $T^{*}$. Basically, the rainfall and surface wind change patterns are very similar between the two methods. In fact, the major features in Fig. 7a are largely reproduced by both methods, illustrating the importance 

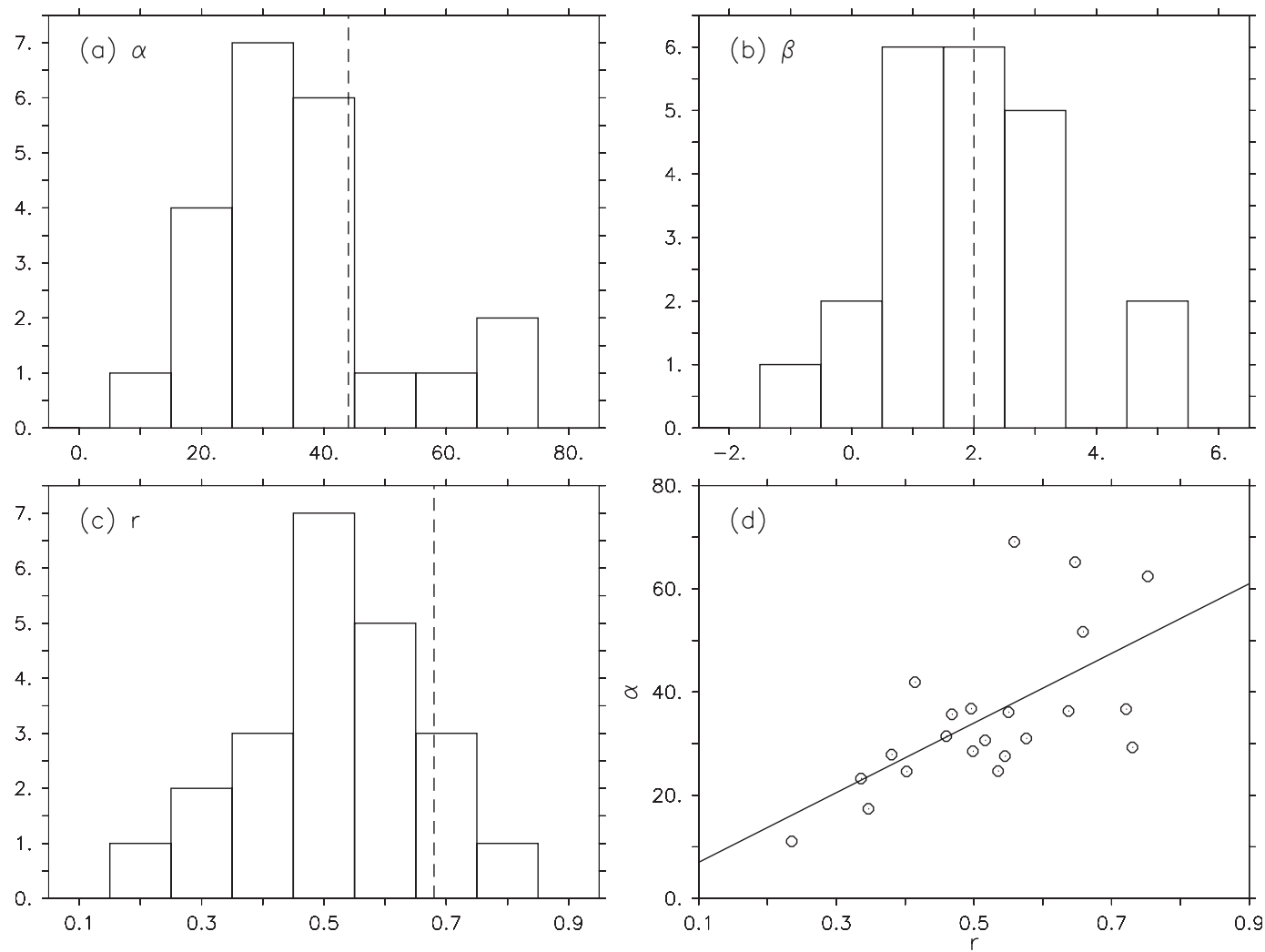

FIG. 5. Histogram of (a) $\alpha$, (b) $\beta$, and (c) $r$ for individual models. Dashed lines mark the ensemble mean values.

(d) Scatterplot between $r$ and $\alpha ; \alpha$ and $\beta$ are defined in Eq. (3), and $r$ denotes the correlation between $\delta P / P$ and $T^{*}$.

of SST patterns in reorganizing regional precipitation in a changing climate.

Without the equatorial peak in $T^{*}$ (CAM_NEP), it becomes clear that the south-to-north gradient of SST warming (Fig. 7e) is associated with a basin-scale WES feedback in the Pacific and Atlantic (Xie and Philander 1994), with enhanced (reduced) trades collocating with weaker (stronger) SST warming in the southeastern (northeastern) Pacific. Note (see Figs. 7d,e) that the high-pressure center is displaced southwest of the SST minimum in the southeastern Pacific, a feature that needs further investigation. The similarity between Figs. $7 \mathrm{c}$ and $7 \mathrm{~d}$ suggests that the AGCM experiments are linearly additive. Thus, we take the CAM_NEP experiment (Fig. 7e) to separate the SST patterns into two modes: the equatorial peak and interhemispheric asymmetry. Calculated as CAM_T* minus CAM_NEP, the equatorial peak effect (Fig. 7f) is accompanied by meridional surface wind convergence, associated with rainfall increase on the equator and reduction on the sides. It also contributes to the reduction of the Walker circulation.

The above analysis shows that the CMIP3 ensemblemean SST warming pattern is composed of two leading modes: the equatorial peak and south-to-north gradient.
SST patterns interact with the atmospheric circulation and dominate rainfall reorganization.

\section{Intermodel variations in precipitation change}

SST and precipitation changes vary considerably among models, and we show that their intermodel variations are correlated over ocean. An intermodel EOF analysis is performed on the SST changes among the CMIP3 models in the tropics $\left(20^{\circ} \mathrm{S}-20^{\circ} \mathrm{N}\right)$. Figure 8 shows the leading modes with regressions for several variables. The first mode represents intermodel variability in cross-equatorial SST gradient, with large SST anomalies in the subtropics. Note that $T^{*}$ (Fig. 8a), air temperature (Fig. 8c), and $\delta P / P$ (consistent with the low-level moisture convergence) (Fig. 8e) are all asymmetric between the hemispheres, with a warmer and wetter Northern Hemisphere. The surface wind (Fig. 8a) and vertical wind shear (Fig. 8c) show consistent baroclinic patterns, suggestive of a basin-scale WES feedback, with enhanced (reduced) trades in the Southern (Northern) Hemisphere.

The second modes are more symmetric about the equator (Figs. 8b,d,f), with enhanced rainfall collocated 
(a) $P-E$

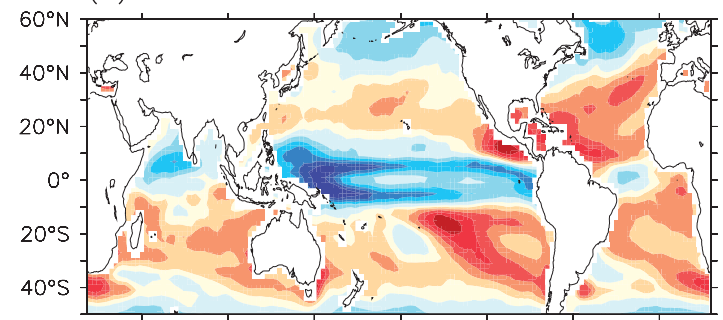

(c) Moisture

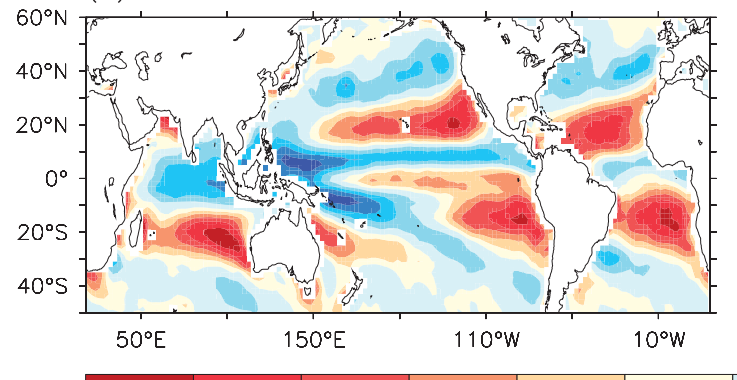

(b) Circulation

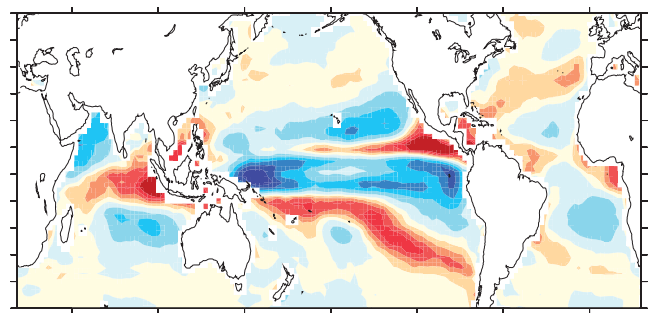

(d) Eddy (Residue)

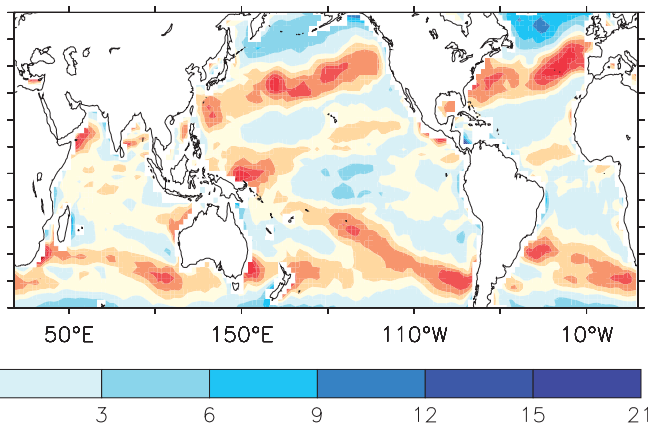

FIG. 6. Annual-mean moisture budget terms [Eq. (2), $\mathrm{mm} \mathrm{month}^{-1}$ ] in CMIP3 ensemble mean, including (a) the total change of precipitation minus evaporation, and the atmospheric (b) dynamic (circulation), (c) thermodynamic (moisture), and (d) eddy components. The vertical integration is performed in the troposphere (200-1000 hPa). The eddy term is calculated as the residual.

with positive SST anomalies in the equatorial Pacific. The equatorial peak warming contributes to the slowdown of the Pacific Walker circulation, which can be seen for both surface wind (Fig. 8b) and vertical wind shear (Fig. 8d). It is noteworthy that the equatorial mode of intermodel variability peaks in the western Pacific. In Xie et al. (2010), anomalous warm oceanic advection due to the weakened south equatorial current is important in this region. Indeed, the intermodel variability in SST warming over the central equatorial Pacific is associated with the net surface heat flux that damps the SST signal (not shown), indicative of an ocean dynamic origin. Thus, the coherence between surface wind and SST patterns in the western equatorial Pacific indicates the model dependency on air-sea interaction processes there.

Reduced warming in the Southern Hemisphere subtropics and the equatorially enhanced warming are dominant patterns of SST response to global warming (Figs. 3a,b). Our EOF analysis above shows that models display considerable differences in representing the magnitude of these patterns. Remarkably, the leading two EOF modes for SST explain about one-third of the intermodel spread in precipitation projection (Table 4). The EOF analysis has been repeated for zonal mean SST, yielding the interhemispheric and equatorial patterns as the leading modes (Fig. 9). The SST modes explain $36 \%$ of the intermodel variability in zonal-mean precipitation (Table 4). The strong SST regulation of variability in rainfall change among models indicates that SST patterns are an important source of uncertainty for regional rainfall projection.

The ensemble-mean patterns of SST change in RCP4.5 (not shown) are similar to those in CMIP3, and well correlated with rainfall change at $r=0.69$. The intermodel variance is larger in RCP4.5 than in A1B with similar modes. Coherent rainfall change is associated with SST modes of intermodel variability.

\section{Overturning circulation change}

As is clear in section 3, the interaction between SST warming pattern and atmospheric circulation change helps shape regional rainfall change. In zonal mean, rainfall is associated with the Hadley circulation. This section investigates what controls the intensity change of tropical overturning circulation in global warming, and the role of SST warming pattern in particular. Our results are presented based on three datasets: AGCM experiments to understand the CMIP3 ensemble mean response, CFMIP2 simulations as part of CMIP5, and intermodel variability in CMIP3. The Hadley circulation is represented by the zonal-integrated meridional mass streamfunction $\psi$, and the Walker circulation by 
(a) CAM_A1B

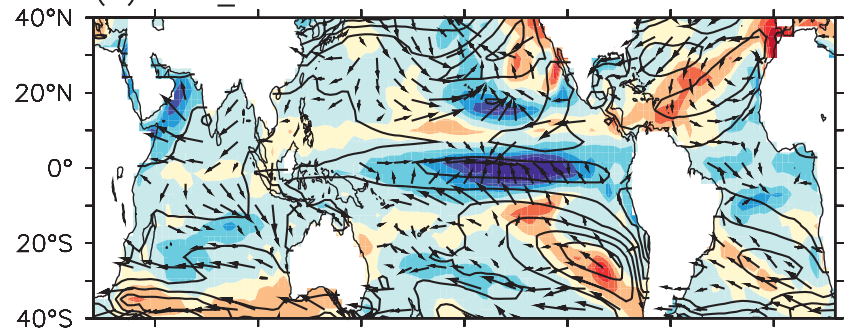

(c) CAM_A1B-CAM_SUSI

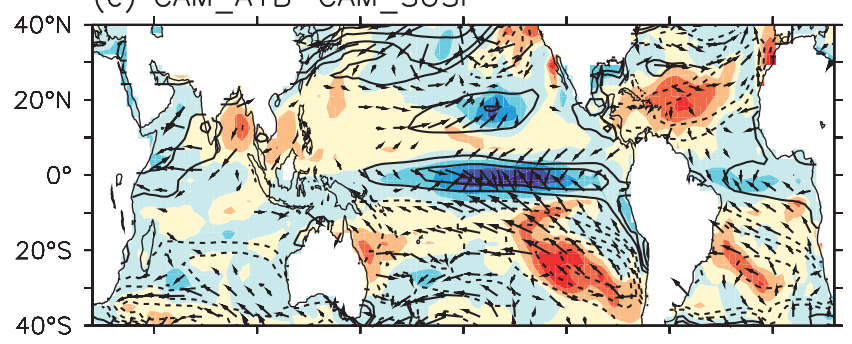

(e) CAM_NEP

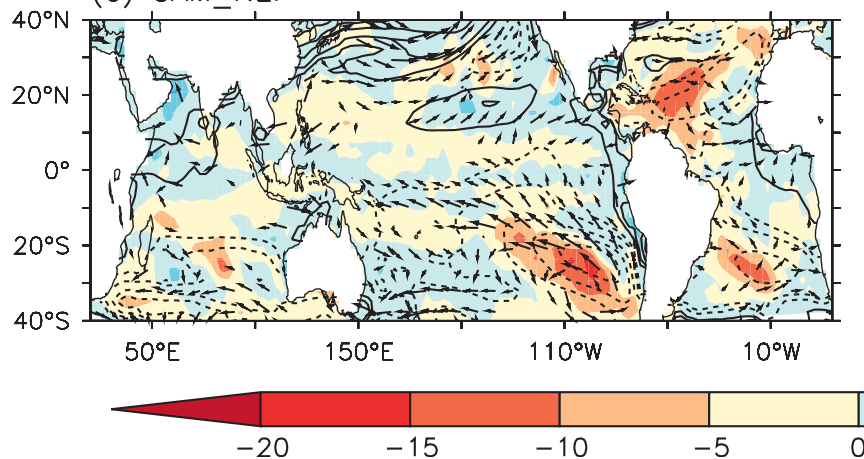

(b) CAM_SUSI

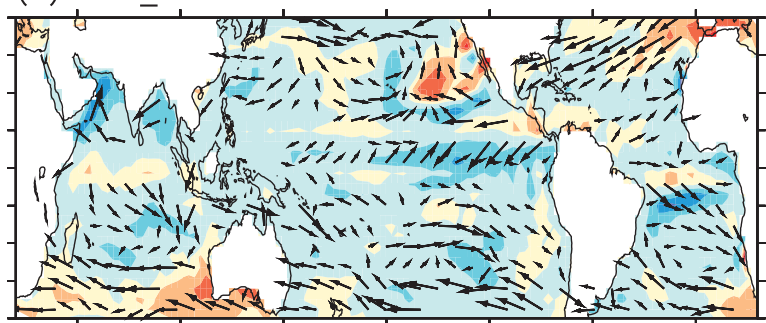

(d) CAM_T*

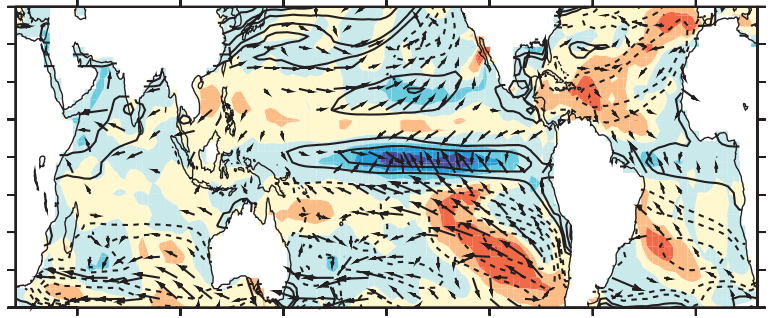

(f) CAM_EP

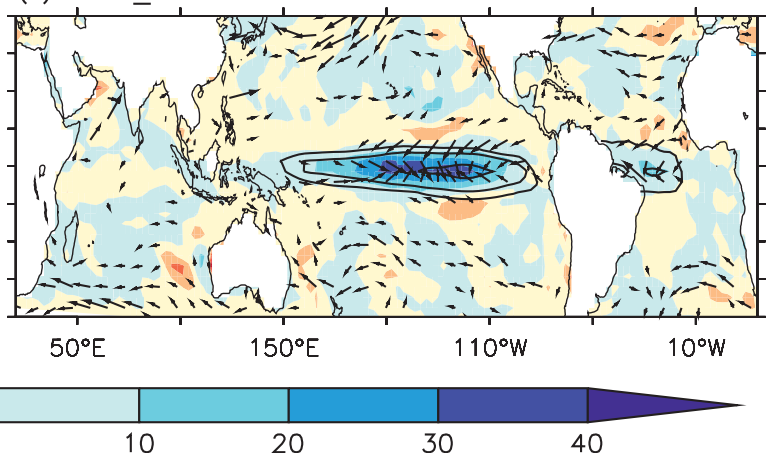

FIG. 7. Percentage rainfall change $\delta P / P$ (shading, \%) and surface winds (vectors, $\mathrm{m} \mathrm{s}^{-1}$ ) simulated by the AGCM experiments with the NCAR CAM3.1. SST forcing for each experiment is shown in contours (CI: $0.1 \mathrm{~K}$ and $0.05 \mathrm{~K}$ adjacent to 0 ; $0 \mathrm{~K}$ contour is omitted). (a) The total response forced by CMIP3 A1B ensemble mean SST change is illustrated with the component SST effects including (b) SUSI, (c) result of (a) minus (b) to be compared with (d) relative SST warming, and SST patterns (e) without the equatorial peak and (f) with the equatorial peak only.

upper-tropospheric $(250 \mathrm{hPa})$ velocity potential $\chi$, obtained by solving a Poisson equation for global horizontal wind divergence (Tanaka et al. 2004).

\section{a. AGCM sensitivity experiments}

Figure 10 illustrates the effect of CMIP3 ensemble mean SST pattern on $\psi$ with the CAM experiments. The CMIP3 ensemble-mean Hadley circulation change (Fig. 10a) features a weakening (slight strengthening) in the Northern (Southern) Hemisphere. The CAM_A1B simulation (Fig. 10b) captures the Northern Hemispheric changes well, but predicts a slight reduction in the southern branch of the Hadley cell. Consistent with the MASC theory of Ma et al. (2012), the SUSI effect (Fig. 10c) weakens the Hadley circulation in both hemispheres. Because the southern branch of the Hadley circulation is stronger in CAM than in CMIP3 ensemble mean, the reduction may also be stronger, resulting in the inconsistency between Figs. 10a and 10b.

The $T^{*}$ effect (Fig. 10d) consists of two components: the equatorial peak (Fig. 10f) and interhemispheric asymmetry (Fig. 10e). The equatorial peak of the SST warming enhances the Hadley cell on either side of the equator, similar to El Niño response (e.g., Chou and Tu 2008). The south-to-north SST warming gradient causes a cross-equatorial circulation with an enhanced southern Hadley cell and a reduced northern one. The midlatitude part of the Hadley cell is complex and likely involves eddy effects (Schneider et al. 2010) and land snow and sea ice feedbacks.

In total, both the SUSI and $T^{*}$ effects contribute to the reduction of the Hadley circulation in the Northern Hemisphere, but $T^{*}$ is the key factor for the enhancement of the southern Hadley cell. This is consistent with 
(a)

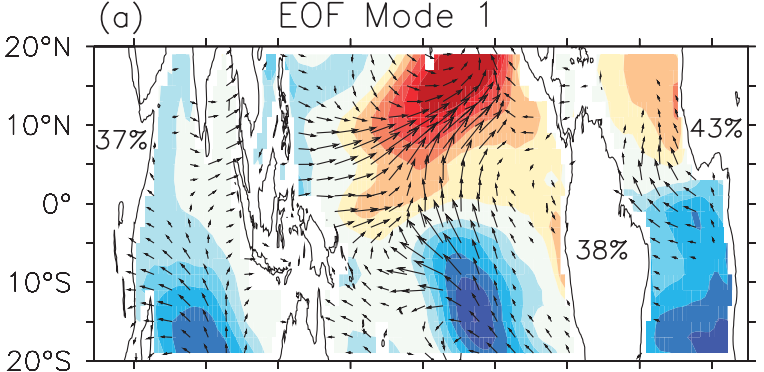

(c)

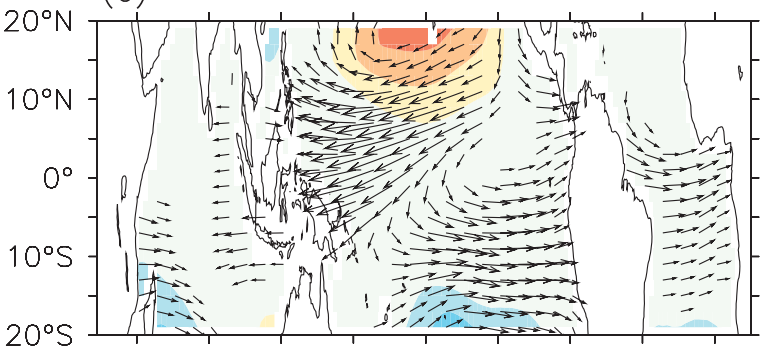

(e)

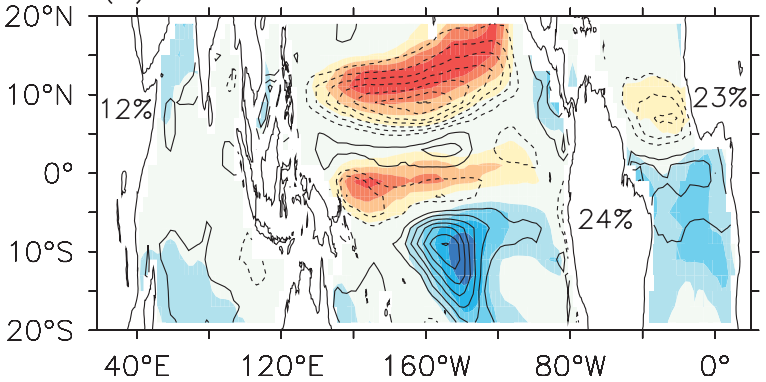

(b)

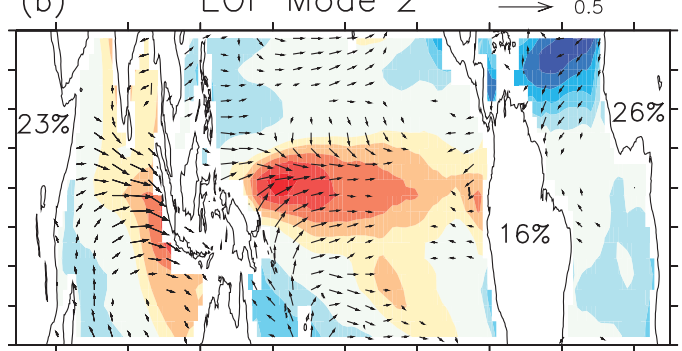

(d)

EOF Mode 2

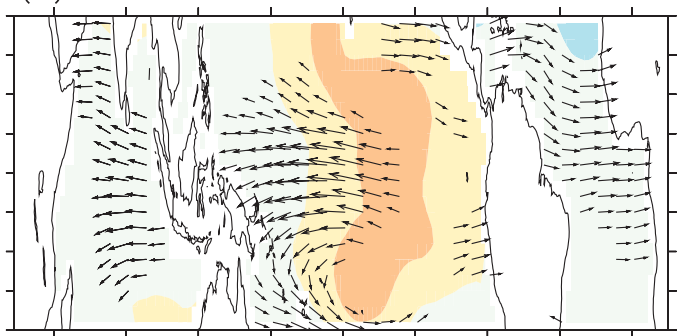

(f)

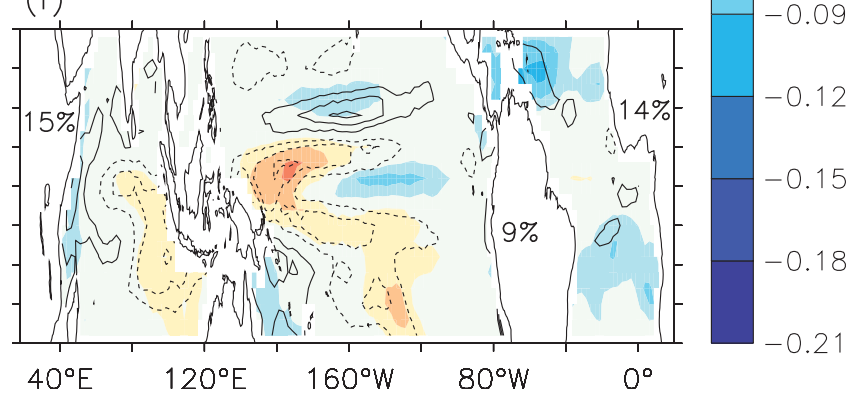

FIG. 8. Leading EOF modes of intermodel SST variability [color shading in (a) and (b)] in CMIP3 A1B projections, normalized by tropical mean SST warming: EOF (left ) 1 and (right) 2. The SST EOF analysis is done within each ocean basin and the explained variance for each mode is marked on a neighboring continent. Regressions on these modes are conducted for (a),(b) surface winds (vectors), (c),(d) tropospheric $(300-850 \mathrm{hPa})$ temperature (color shading) and vertical wind shear (vectors); and (e),(f) $\delta P / P$ (color shading; variance explained by each SST mode marked for each basin) and 700-1000-hPa moisture divergence (contours).

the finding of Ma et al. (2012) that the spread of crossequatorial SST gradient explain much variability in the intensity change of the Southern Hadley cell among CMIP3 models, a point we return to in section 5c.

Figure 11 shows the horizontal distribution of the changes in $250-\mathrm{hPa} \chi$ and divergent wind in the CMIP3 ensemble mean and various CAM sensitivity experiments. The slowdown of the Pacific Walker circulation is apparent in the CMIP3 ensemble mean (Fig. 11a), featuring anomalous convergence-downward motion over the Indo-Pacific warm pool and divergence-upward motion over the eastern Pacific. The CAM_A1B experiment (Fig. 11b) captures the change quite well $(r=$ $0.87)$. The magnitude of the change is somewhat larger in CAM, since the ensemble mean damps the response of the CMIP3 models. The major contributor to the Walker circulation slowdown is the SUSI effect (Fig. 11c), which has very high spatial correlation $(r=0.96)$ with CAM_A1B. The SST pattern (Fig. 11d) only has a weak weakening effect on the Walker cell, mainly due to the equatorial peak warming (Fig. 11f). The meridional gradient of SST warming (Fig. 11e) does not contribute to the Walker circulation change. Indeed, the SUSI effect dominates the upper-tropospheric circulation change, including the slowdown of the Hadley circulation (Fig. 10).

\section{b. CMIP5-CFMIP2 simulations}

The CFMIP2 experiments isolate the direct radiative RAD, SUSI, and SST pattern effects from the CMIP5

TABLE 4. Intermodel variance explained by the two leading EOF modes of SST variability $\left(20^{\circ} \mathrm{S}-20^{\circ} \mathrm{N}\right)$.

\begin{tabular}{lcccc}
\hline \hline$\%$ & Pacific & Atlantic & Indian Ocean & Zonal mean \\
\hline$T^{*}$ & 54 & 69 & 60 & 84 \\
$\delta P / P$ & 33 & 37 & 27 & 36 \\
\hline
\end{tabular}




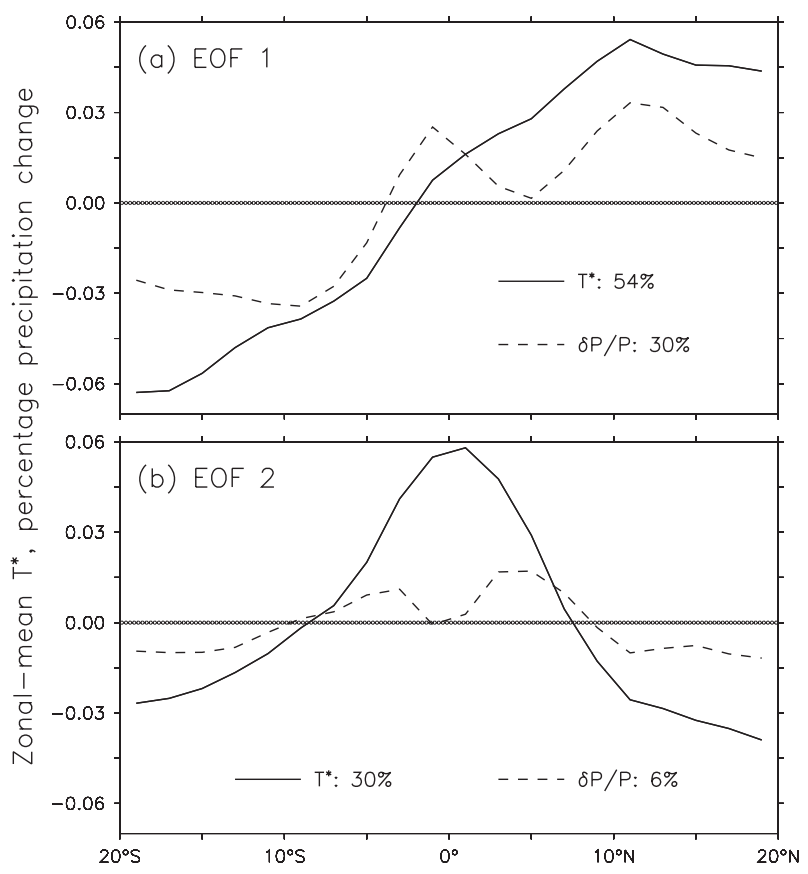

FIG. 9. Intermodel EOF modes of zonal-mean SST changes and regression of zonal-mean $\delta P / P$ in the CMIP $3 \mathrm{~A} 1 \mathrm{~B}$ ensemble: EOF (top) 1 and (bottom) 2.

coupled models. The Hadley circulation is represented by $\psi$ at $500 \mathrm{hPa}$, and the Walker circulation by $250-\mathrm{hPa}$ equatorial $\left(15^{\circ} \mathrm{S}-15^{\circ} \mathrm{N}\right) \chi$.

Figure 12 shows the $500-\mathrm{hPa} \psi$ changes due to different factors. The SUSI effect (Fig. 12a) tends to reduce the Hadley cell in all models. Since the MASC effect (Ma et al. 2012) is supposed to be identical among models, the intermodel variations come mainly from those in latent heating. The $\mathrm{CO}_{2}$ RAD effect (Fig. 12c) slightly reinforces the SUSI, especially in the Northern Hemisphere. The equatorial peak in SST warming (Fig. 12b) accelerates the Hadley cell near the equator. In the subtropics, the south-to-north warming gradient significantly accelerates the southern cell. The combined effect (Fig. 12d) makes a robust slowdown of the Hadley circulation in the northern subtropics. In the region near and south of the equator, by contrast, the opposing SUSI and SST pattern effects result in weak and highly uncertain ensemble-mean Hadley circulation strength change, subject to intermodel differences brought by SST pattern and model physics. This is consistent with the CMIP3 results (Fig. 14a) and CAM experiments (Fig. 10).

The 250-hPa $\chi$ (Fig. 13) shows a robust slowdown of the Pacific Walker circulation in SUSI (Fig. 13a). The RAD effect (Fig. 13c) weakly enhances the Walker circulation. The SST pattern (Fig. 13b) brings large uncertainty but does not offset the SUSI effect. As a result, the Walker circulation slowdown is robust (Fig. 13d), similar to the CMIP3 results (Fig. 14b) and CAM experiments (Fig. 11).

The MASC effect (Ma et al. 2012) in SUSI slows down both the Hadley (Fig. 12a) and Walker (Fig. 13a) circulations. The RAD effect is weak (Figs. 12c, 13c). The SST pattern effect (Figs. 12b, 13b) introduces considerable uncertainty to the intensity change in both types of overturning circulation. The ensemble-mean effects of SST pattern are quite different between the Hadley and Walker circulation. Note that $T^{*}$ contributes little to the Walker circulation (Fig. 13b) so its slowdown remains robust (Figs. 13a,d). For the Hadley circulation, by contrast, the ensemble-mean $T^{*}$ counteracts the SUSI and RAD effects (Fig. 12b) and makes $\psi$ flat and uncertain in the southern subtropics and near the equator (Fig. 12d).

\section{c. CMIP3 intermodel variability}

This section investigates the SST pattern effect on intermodel variations in overturning circulation intensity in CMIP3. Figure 14 shows the climatology and change of $500-\mathrm{hPa} \psi\left(\right.$ Fig. $14 \mathrm{a}$ ) and $15^{\circ} \mathrm{S}-15^{\circ} \mathrm{N}$ averaged 250-hPa $\chi$ (Fig. 14b), including both the CMIP3 ensemble mean and spread (shading). For the Hadley streamfunction, there are large intermodel variations in $15^{\circ} \mathrm{S}-15^{\circ} \mathrm{N}$, so large that they can alter the sign of the Hadley circulation strength change in the southern subtropics and equatorial region. In the northern subtropics, the Hadley cell slowdown is robust, consistent with Figs. 10a and 12d. This asymmetry is due to the spatial variations in ensemble mean SST warming as discussed above. The Pacific Walker circulation (Fig. 14b) shows a robust reduction, consistent with previous studies (Vecchi et al. 2006; Vecchi and Soden 2007a). The intermodel variations are on the same order of magnitude as those for the Hadley circulation. Below we investigate the cause of the intermodel variability.

To examine the SST pattern effect on the intermodel variations of the overturning circulation changes, we perform two sets of intermodel SVD analyses among the CMIP3 GCMs. One is between the zonal mean SST patterns and $500-\mathrm{hPa} \psi$, and the other is between the equatorial SST patterns and $250-\mathrm{hPa} \chi$. Specifically, a conventional SVD analysis is applied to 22 pairs of variables simulated by the 22 CMIP3 models.

The meridional SST modes (Fig. 15) resemble the leading EOF modes (Figs. 8a,b), featuring the south-tonorth gradient and the equatorial peak, respectively (Ma et al. 2012). Both modes significantly influence $\psi$ in the region of high intermodel variability (Fig. 14a). The first SVD mode (Fig. 15a) is antisymmetric with positive (negative) anomalous SST in the Northern (Southern) 
(a) CMIP3

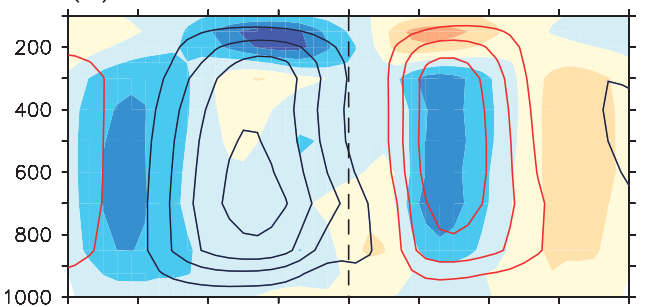

(c) CAM_SUSI

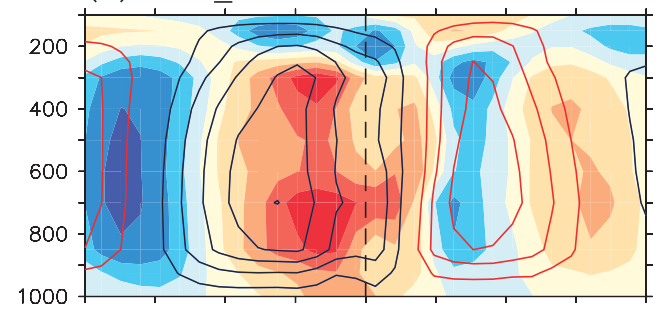

(e) CAM_NEP

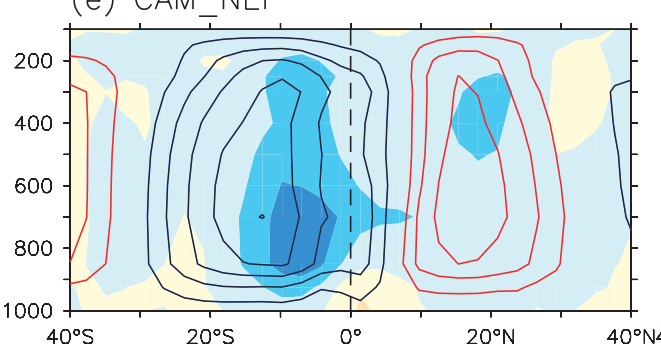

(b) CAM_A1B

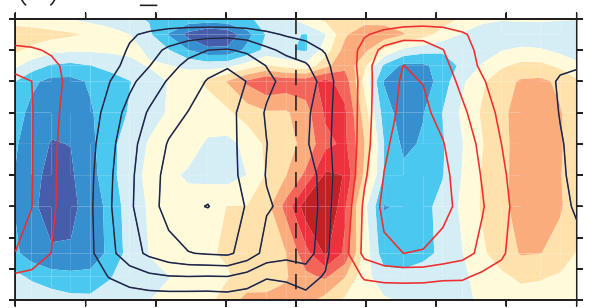

(d) $\mathrm{CAM}_{-} \mathrm{T}^{*}$

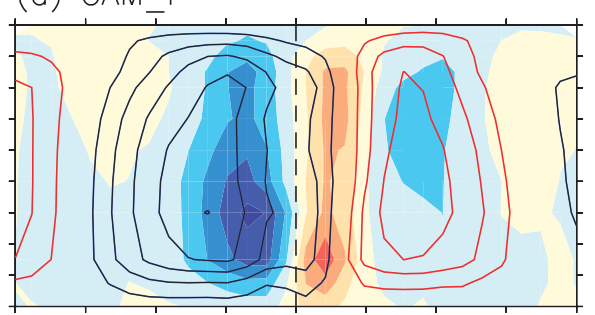

(f) CAM_EP

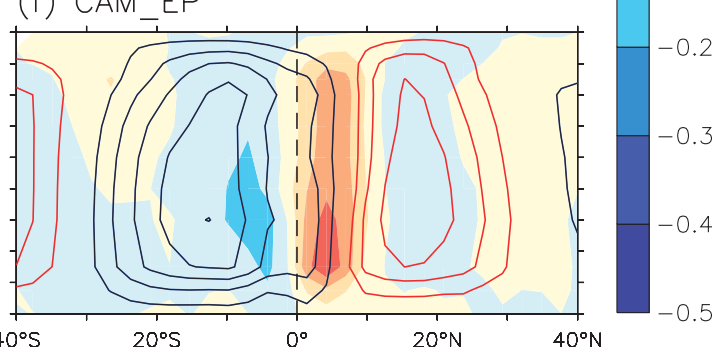

FIG. 10. Annual mean changes of the Hadley circulation in (a) the CMIP3 ensemble mean and various CAM simulations, including (b) the total response forced by CMIP3 A1B ensemble mean SST change, and the component SST effects of (c) SUSI, (d) relative SST warming, and SST patterns (e) without the equatorial peak and (f) with the equatorial peak only. The Hadley circulation is represented by the zonally integrated meridional streamfunction (color shading, $10^{10} \mathrm{~kg} \mathrm{~s}^{-1}$ ), with the contours ( $\mathrm{CI}$ is $2 \times 10^{10} \mathrm{~kg} \mathrm{~s}^{-1}$; red for positive and blue for negative; 0 contour is omitted) showing the mean circulation for reference.

Hemisphere. This causes a cross-equatorial anticlockwise circulation between $15^{\circ} \mathrm{S}$ and $15^{\circ} \mathrm{N}$ that represents an enhanced (weakened) Hadley cell south (north) of the equator. The second mode (Fig. 15b) is symmetric and features an enhanced Hadley circulation on either side of the equator (within $20^{\circ} \mathrm{S}-20^{\circ} \mathrm{N}$ ), driven by the equatorial peak of SST warming, similar to the response to El Niño (Chou and Lo 2007; Chou and Tu 2008). The leading zonal modes (Fig. 16) represents intermodel variability in zonal SST gradient across the Pacific (Fig. 8b), associated with changes in the Walker circulation.

Then, we remove the first two SVD modes of $\psi$ and $\chi$ from intermodel variability. Intermodel variations of the Hadley and the Pacific Walker circulations are both dramatically reduced (Fig. 14), indicating that the SST warming pattern is a major source of uncertainty in changes of overturning circulations. This does not come as a surprise as the leading two modes explain $82 \%$ and $69 \%$ of the intermodel variability in the Hadley (Fig. 15) and Walker (Fig. 16) circulation, respectively. The residual uncertainty may be due to differences in model physics.
Figure 14 sheds light on the reason why the Hadley circulation intensity change is not as robust as the Walker circulation. Because intermodel variations in SST pattern induce uncertainty for both types of circulation, the magnitude of the ensemble mean changes becomes important. The slowdowns of the Walker and northern Hadley cells are robust because of large ensemble-mean changes. The Hadley circulation change near and south of the equator is not robust because of small ensemble-mean change. This is illustrated more clearly by the CMIP5-CFMIP2 results (Figs. 12 and 13).

To illustrate the relationship between overturning circulation change and SST warming pattern, we devise indices for the southern Hadley cell (with most uncertainty) and Pacific Walker cell as follows:

- Southern Hadley cell index $=500-\mathrm{hPa} \psi$ averaged in $15^{\circ}-5^{\circ} \mathrm{S}$, and SST meridional gradient index $=$ SST averaged in $5^{\circ} \mathrm{S}-5^{\circ} \mathrm{N}$ minus that in $25^{\circ}-15^{\circ} \mathrm{S}$.

- Pacific Walker cell index $=250-\mathrm{hPa}$ equatorial $\left(15^{\circ} \mathrm{S}-15^{\circ} \mathrm{N}\right) \chi$ averaged in $100^{\circ}-140^{\circ} \mathrm{W}$ minus that in 
(a) CMIP3

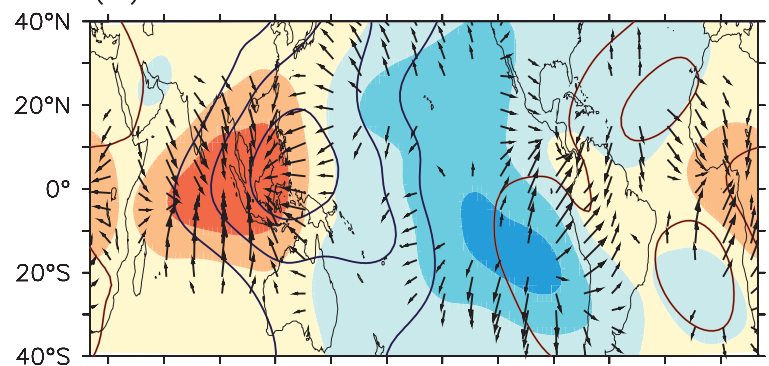

(c) CAM_SUSI

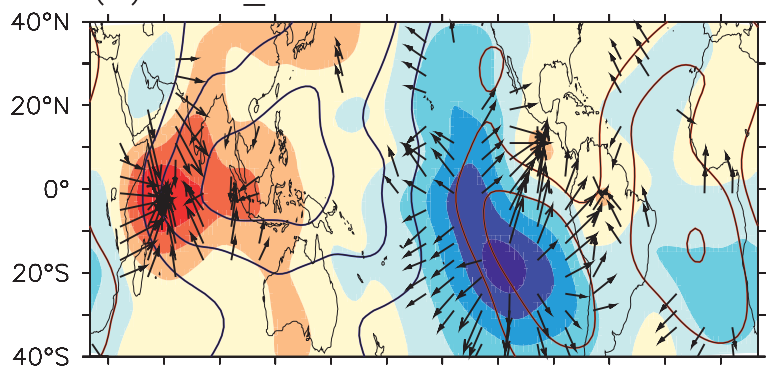

(e) CAM_NEP

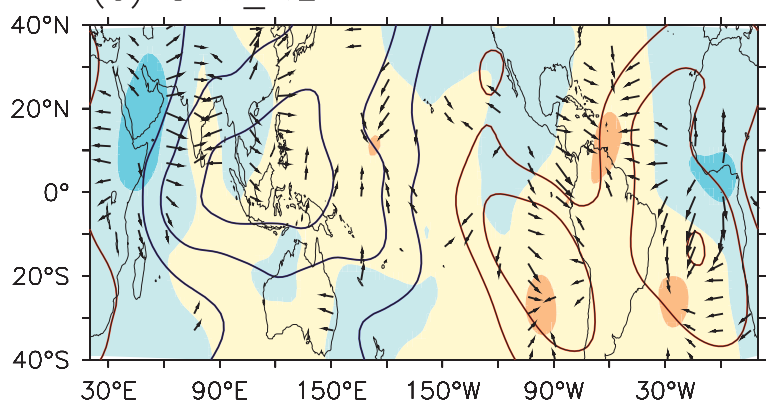

(b) CAM_A1B

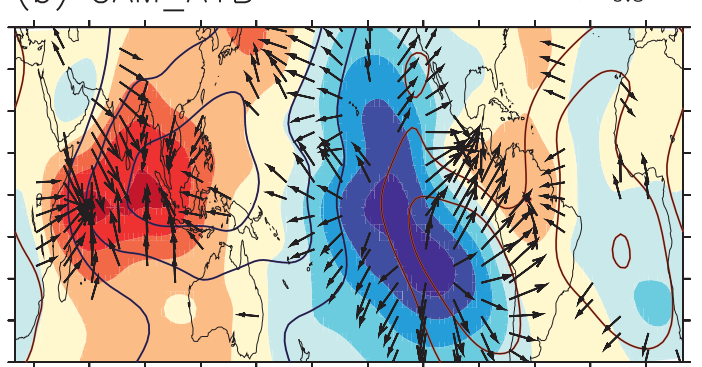

(d) CAM_T*

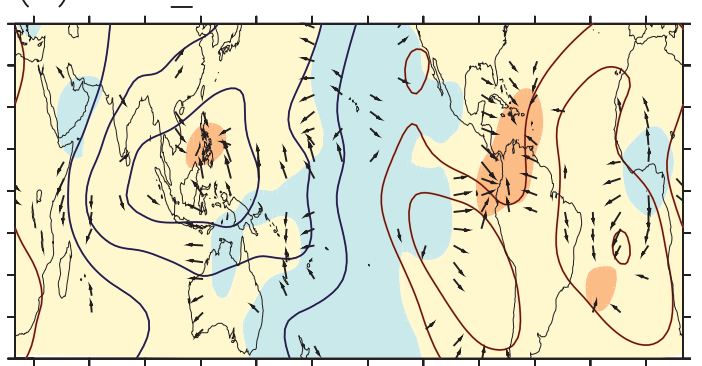

(f) CAM_EP

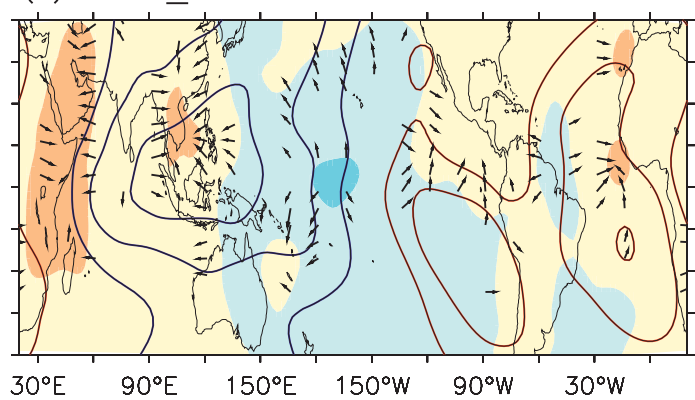

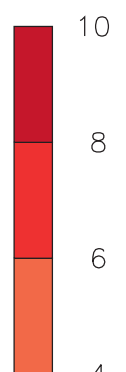

4

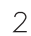

0

$-2$

FIG. 11. As in Fig. 10, but for the Walker circulation represented by the 250-hPa velocity potential (color shading, $10^{5} \mathrm{~m}^{2} \mathrm{~s}^{-1}$ ) and divergent wind (vectors, $\mathrm{m} \mathrm{s}^{-1}$ ), with the contours (CI: $20 \times 10^{5} \mathrm{~m}^{2} \mathrm{~s}^{-1}$; red for positive and blue for negative; the 0 contour omitted) showing the mean velocity potential for reference.

$80^{\circ}-120^{\circ} \mathrm{E}$, and SST zonal gradient index $=$ equatorial $\left(5^{\circ} \mathrm{S}-5^{\circ} \mathrm{N}\right) \mathrm{SST}$ averaged in $100^{\circ}-140^{\circ} \mathrm{W}$ minus that in $80^{\circ}-120^{\circ} \mathrm{E}$.

Intermodel variations are correlated between SST pattern and overturning circulation change at -0.74 and -0.44 for the Hadley and Walker circulations, respectively (Fig. 17). The linear relation predicts the overturning circulation slowdown in SUSI where SST gradient reaches zero. For the southern Hadley cell (Fig. 17a), the predicted SUSI reduction is $0.4 \times 10^{10} \mathrm{~kg} \mathrm{~s}^{-1}$, which is cross-validated by the CMIP5-CFMIP2 SUSI results. However, because the SST pattern effect is strong, the total change in the southern Hadley cell is weak and highly uncertain. For the Pacific Walker cell (Fig. 17b), the predicted SUSI reduction is also consistent with the CMIP5-CFMIP2 results. The SST pattern contributes to the slowdown at about one-third of the total magnitude. Thus, the weakening of the Walker circulation is robust.

\section{Conclusions and discussion}

We have investigated the relationship among SST, precipitation, and atmospheric circulation changes in response to global warming using a large ensemble of CMIP simulations. While SST increases everywhere, precipitation change is to first order variable in space. Spatial patterns of SST warming play a key role in determining precipitation change. Our results show that in the ensemble mean, the annual mean rainfall change over tropical oceans follows a "warmer-get-wetter" pattern. Our moisture budget analysis shows that this SST control is not simply a result of spatial variations in water vapor increase (the Clausius-Clapeyron relation) 
(a) SUSI

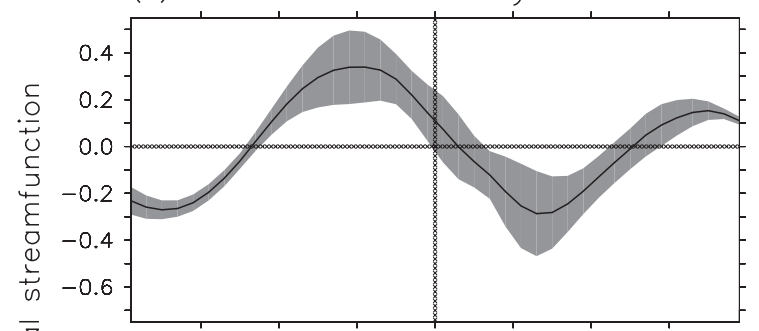

(c) RAD

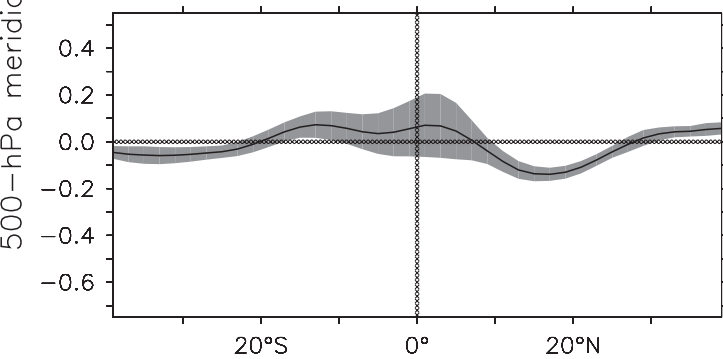

(b) $T^{*}$

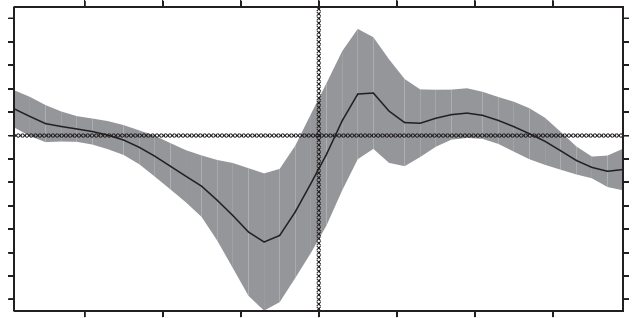

(d) Coupled models

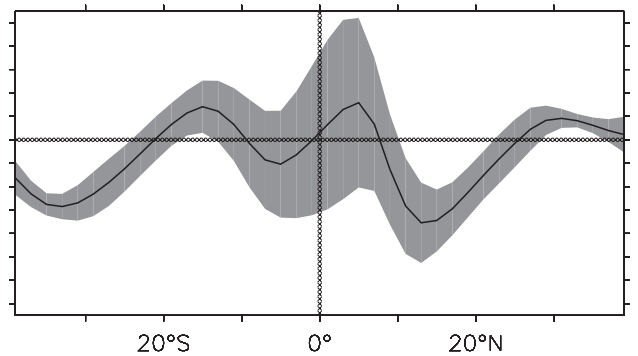

FIG. 12. Annual mean changes of the $500-\mathrm{hPa}$ zonal-integrated meridional streamfunction $\left(10^{10} \mathrm{~kg} \mathrm{~s}^{-1}\right)$ in CMIP5-CFMIP2 simulations including atmospheric response to the (a) SUSI, (b) SST patterns, and (c) direct GHG radiative effect, and (d) in the GHG-forced coupled models. The shading marks the uncertainty (ensemble mean \pm standard deviation) among the five models.

but occurs through adjustments in atmospheric circulation (Chou et al. 2009). Because equatorial waves flatten the tropospheric warming to a value determined by tropical-mean SST warming, the threshold for tropical convection rises, and the SST pattern and associated moisture change dominate the rainfall response. In many parts of tropical oceans, convection is reduced despite an increase in local SST because the local warming falls below the tropical average. In other parts of the tropics where relative SST change is positive, precipitation generally increases. The warmer-get-wetter pattern dominates in coupled models and deviates from the "wet-get-wetter" pattern realized in atmospheric response to uniform SST increase. (a) SUSI

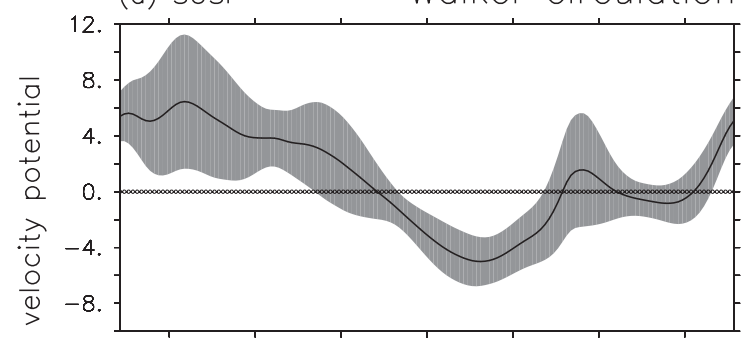

(c) RAD

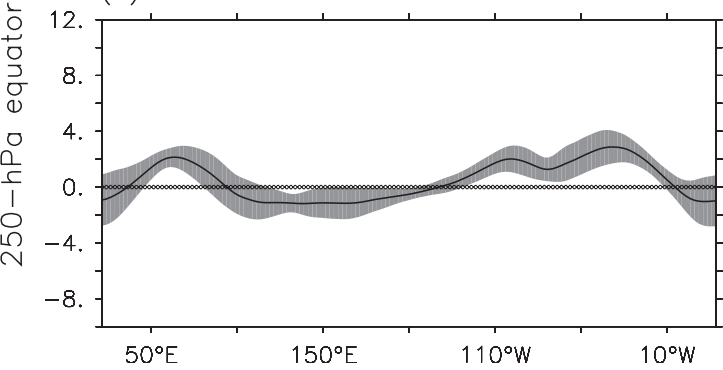

(b) $T^{*}$

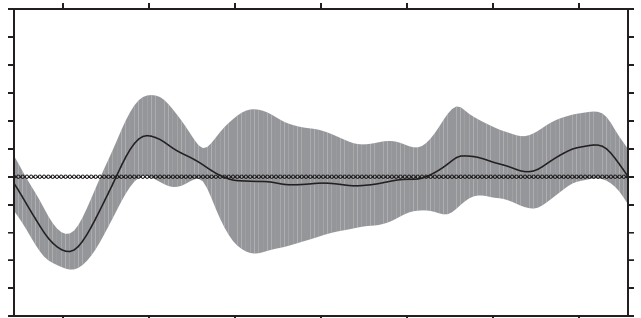

(d) Coupled models

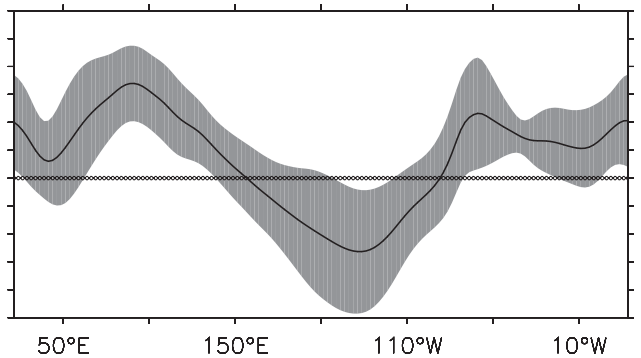

FIG. 13. As in Fig. 12, but for the $15^{\circ} \mathrm{S}-15^{\circ} \mathrm{N}$ averaged 250 -hPa velocity potential $\left(10^{5} \mathrm{~m}^{2} \mathrm{~s}^{-1}\right)$. 
(a) Hadley circulation

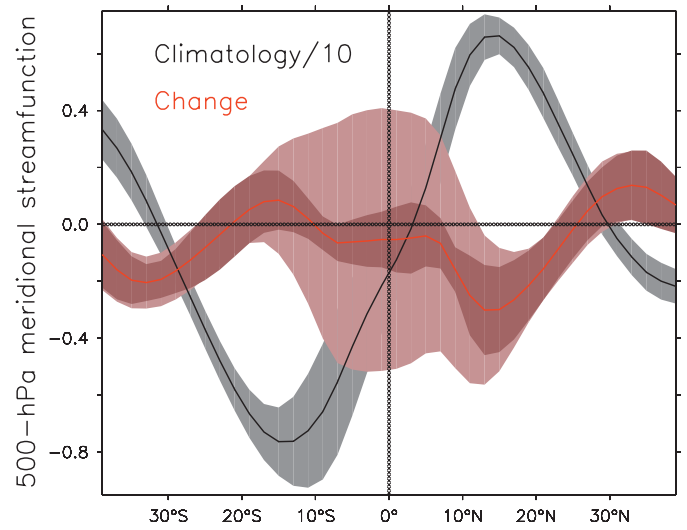

(b) Walker circulation

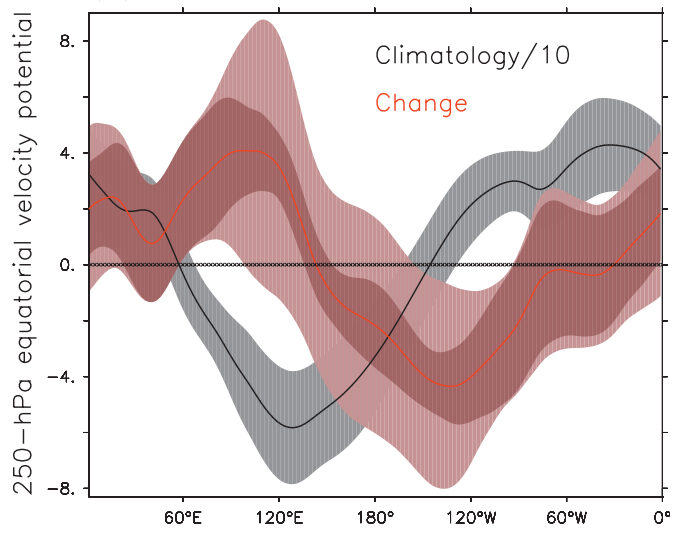

FIG. 14. Annual mean climatology and changes of the (a) 500-hPa zonal-integrated meridional streamfunction $\left(10^{10} \mathrm{~kg} \mathrm{~s}^{-1}\right)$, and (b) $15^{\circ} \mathrm{S}-15^{\circ} \mathrm{N}$ averaged 250 -hPa velocity potential $\left(10^{5} \mathrm{~m}^{2} \mathrm{~s}^{-1}\right)$ in CMIP3 A1B simulations. Gray (light red) shading marks the uncertainty (ensemble mean \pm standard deviation) of the 22 GCMs in climatology (change). The dark red shading marks the reduced uncertainty by removing the first two SVD modes on SST. The figure is scaled by the climatology so that one can compare the Hadley and Walker circulations.

As illustrated in Fig. 1, take any two global warming simulations, and the differences in projected rainfall change are obvious and substantial. Our results show that differences in patterns of SST warming explains about one-third of intermodel variability in tropical rainfall change among CMIP3 models.

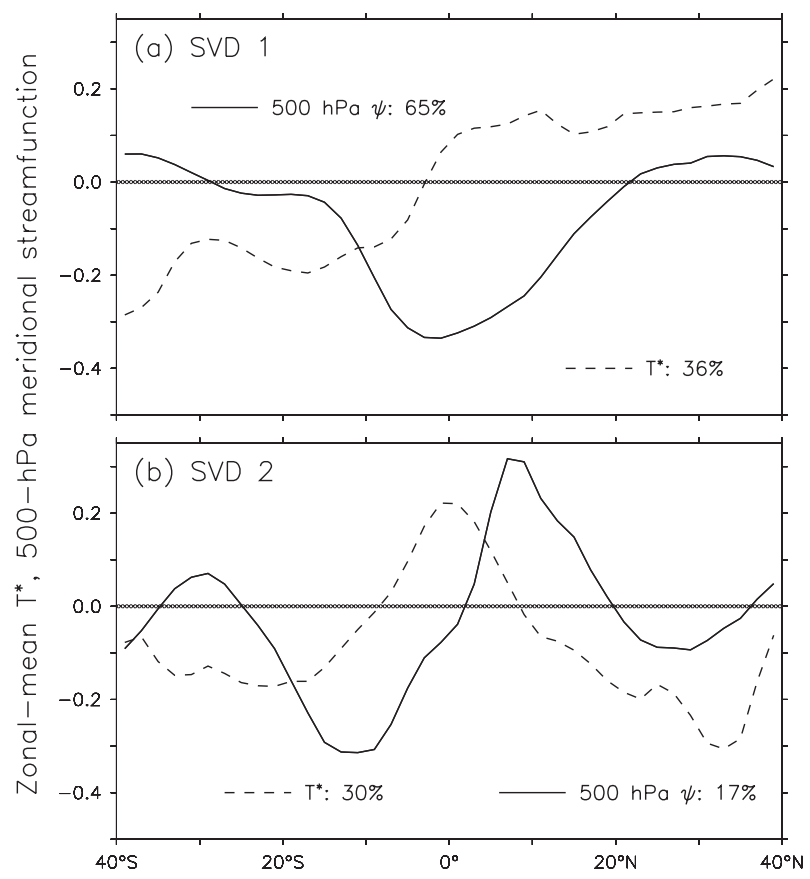

FIG. 15. First two modes of the intermodel SVD analysis between the annual mean changes of zonal mean SST patterns and 500-hPa zonally integrated meridional streamfunction among the 22 CMIP3 GCMs under the A1B scenario: SVD (top) 1 and (bottom) 2. Reproduced from Ma et al. (2012).
Both the ensemble mean and intermodel variability feature two major patterns of SST change: the equatorial peak and cross-equatorial gradient. The equatorial peak drives low-level moisture convergence and enhances local convection-precipitation. The south-to-north gradient pattern is associated with interhemispheric WES feedback, with enhanced (reduced) trades and
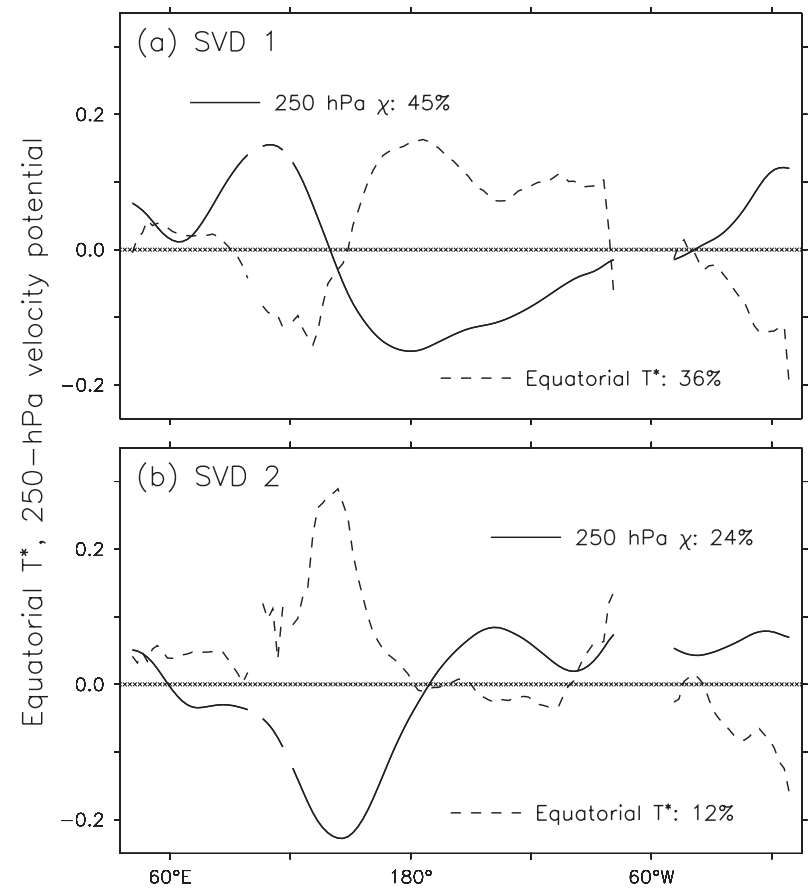

FIG. 16. As in Fig. 15, but for SST and 250-hPa velocity potential along the equator, averaged over $5^{\circ} \mathrm{S}-5^{\circ} \mathrm{N}$ and $15^{\circ} \mathrm{S}-15^{\circ} \mathrm{N}$, respectively. 

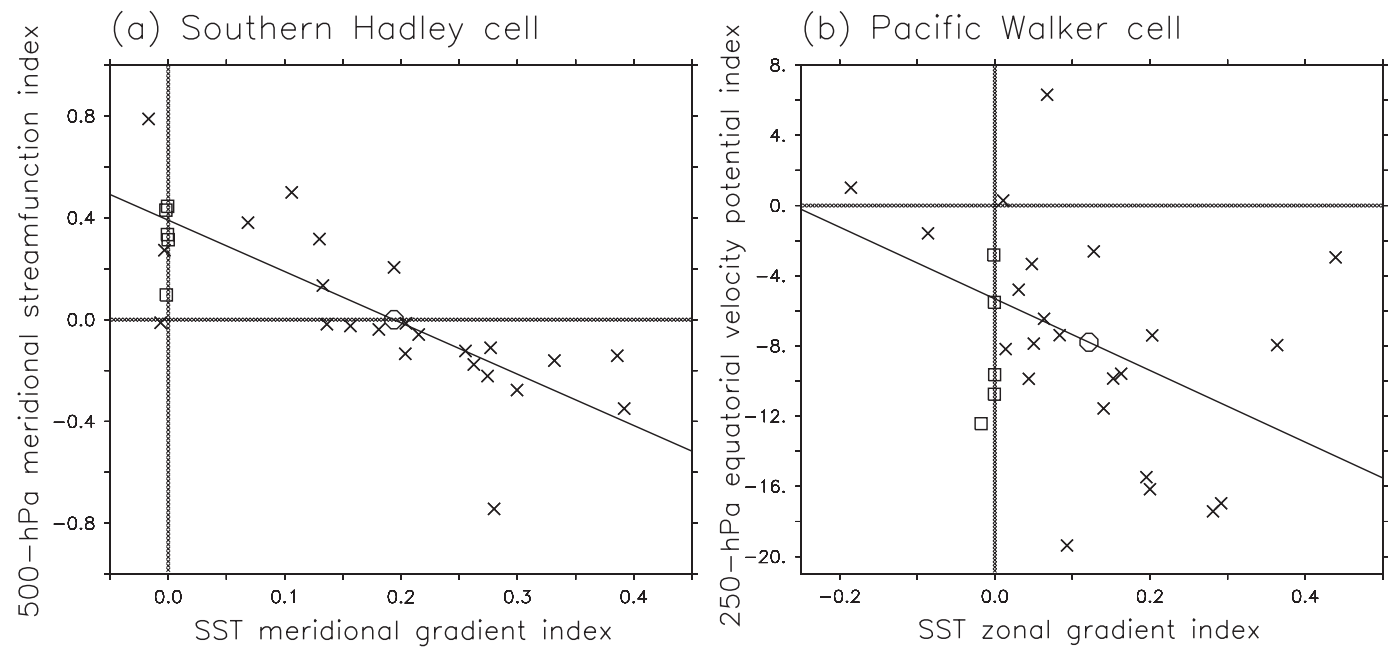

FIG. 17. Scatterplot between SST gradient and overturning circulation change across the CMIP3 A1B models (cross). (a) SST meridional gradient index vs southern Hadley cell index. (b) SST zonal gradient index vs Pacific Walker cell index. Also marked are the ensemble mean of the CMIP3 models (circle) and SUSI runs of the CMIP5CFMIP2 models (squares).

drying (wetting) in the Southern (Northern) Hemisphere. These patterns are robust in the CMIP3 ensemble mean but their magnitude varies among models. The diversity in representing these two modes among models is an important source of uncertainty for rainfall projection over tropical oceans. We note that the ensemble mean tends to underestimate the spatial variations. For individual models, the spatial standard deviations of SST warming in $20^{\circ} \mathrm{S}-20^{\circ} \mathrm{N}$ are $0.19 \pm 0.04 \mathrm{~K}$ for a nominal $1-\mathrm{K}$ tropical-mean warming, considerably higher than the ensemble mean $(0.12 \mathrm{~K})$. If nature evolves as one of the model realizations, the importance of the SST change patterns would be more significant than what we have shown for the ensemble mean.

Both the SUSI and SST pattern effects are important for the Hadley and Walker circulation intensity change in global warming. If the SST warming were spatially uniform, the Hadley and Walker circulation would both slow down as articulated in previous studies (Held and Soden 2006; Vecchi et al. 2006; Ma et al. 2012). The equatorial-peaked warming accelerates the Hadley circulation on either side of the equator while the reduced warming in the Southern Hemispheric accelerates the southern Hadley cell. As a result of combined SUSI and SST pattern effect, the northern Hadley cell shows a robust slowing down while the Hadley circulation strength changes near and south of the equator are weak in the ensemble mean and subject to large intermodel variability. Uncertainty in SST warming pattern, dominated by the equatorial peak and cross-equatorial gradient modes, accounts for a whopping $82 \%$ of intermodel variability in Hadley circulation change among CMIP3 models. Compared to the Hadley circulation, the SST pattern effect on Walker circulation is weak, and the SUSI effect dominates. As a result, the slowdown of the Walker circulation is a robust feature across the CMIP models.

This study shows that SST patterns are important for future climate change, in the warmer-get-wetter pattern and Hadley circulation response. In addition, the SST pattern can explain the intermodel variations in tropical cyclone frequency response to global warming (Zhao and Held 2012). The tropical SST effect is not limited to the tropics as shifts in tropical convection and circulation have major remote effects on climate change elsewhere, via atmospheric teleconnection (Shin and Sardeshmukh 2011) and by affecting modes of climate variability (Collins et al. 2010; Zheng et al. 2010).

The rainfall-SST change relationship is similar to that in the mean state and El Niño (i.e., greater precipitation over areas with warmer SST). This is the main reason why the AGCM simulations can capture reasonable precipitation and circulation change. However, the causes of SST pattern formation and the influence of SST patterns on convection and associated circulation involve much more complicated processes including not only the ocean-atmosphere interactions, but also the interaction between convection and large-scale environment.

Recent observational studies reveal robust evidence for air-sea coupling associated with slowing down of the Walker cell and coherent patterns of climate change over tropical oceans (Tokinaga and Xie 2011; Tokinaga et al. 2012). Innovative model experimentations show 
that ocean-atmosphere interactions, specifically the WES feedback, are indeed at work in the formation of major SST warming patterns (Lu and Zhao 2012). To the extent that changes in surface winds and ocean circulation are important for SST patterns, this study calls for investigations into ocean-atmosphere interactions that shape SST and precipitation changes, which is demonstrated to be important for intermodel variability (an important measure of uncertainty) in a large model ensemble.

Acknowledgments. We acknowledge various modeling groups (listed in Table 1 of this paper) for producing and providing their output, the Program for Climate Model Diagnostics and Intercomparison (PCMDI) for collecting and archiving the CMIP3 and CMIP5 (CFMIP2) multimodel data, the WCRP's Working Group on Coupled Modeling (WGCM) for organizing the analysis activity, and the Office of Science, U.S. Department of Energy, for supporting these datasets in partnership with the Global Organization for Earth System Science Portals. We wish to thank M. Webb and M. Ringer for sharing the CFMIP SUSI simulations, the NCAR for the CAM3.1 codes and related data, and K. Hamilton and anonymous reviewers for their helpful comments and suggestions. The Ferret program was used for analysis and graphics. This work is supported by NSF, NOAA, NASA, and JAMSTEC.

\section{REFERENCES}

Back, L. E., and C. S. Bretherton, 2006: Geographic variability in the export of moist static energy and vertical motion profiles in the tropical Pacific. Geophys. Res. Lett., 33, L17810, doi:10.1029/2006GL026672.

Cess, R. D., and Coauthors, 1990: Intercomparison and interpretation of cloud-climate feedback processes in 19 atmospheric general circulation models. J. Geophys. Res., 95, 16 601-16 615.

Chou, C., and J. D. Neelin, 2004: Mechanisms of global warming impacts on regional tropical precipitation. J. Climate, 17, $2688-2701$.

— cipitation during ENSO. J. Climate, 20, 3411-3433.

—_, and J.-Y. Tu, 2008: Hemispherical asymmetry of tropical precipitation in ECHAM5/MPI_OM during El Niño and under global warming. J. Climate, 21, 1309-1332.

— J. D. Neelin, C.-A. Chen, and J.-Y. Tu, 2009: Evaluating the "rich-get-richer" mechanism in tropical precipitation change under global warming. J. Climate, 22, 1982-2005.

Collins, M., and Coauthors, 2010: The impact of global warming on the tropical Pacific Ocean and El Niño. Nat. Geosci., 3, 391397.

Collins, W. D., and Coauthors, 2006: The formulation and atmospheric simulation of the Community Atmosphere Model: CAM3. J. Climate, 19, 2144-2161.

Gastineau, G., L. Li, and H. Le Treut, 2009: The Hadley and Walker circulation changes in global warming conditions described by idealized atmospheric simulations. J. Climate, 22, 3993-4013.

Held, I. M., and B. J. Soden, 2006: Robust responses of the hydrological cycle to global warming. J. Climate, 19, 56865699.

— T. T. Delworth, J. Lu, K. L. Findell, and T. R. Knutson, 2005: Simulation of Sahel drought in the 20th and 21st centuries. Proc. Natl. Acad. Sci. USA, 102, 17 891-17 896.

Johnson, N. C., and S.-P. Xie, 2010: Changes in the sea surface temperature threshold for tropical convection. Nat. Geosci., 3, 842-845, doi:10.1038/ngeo1008.

Leloup, J., and A. Clement, 2009: Why is there a minimum in projected warming in the tropical North Atlantic Ocean? Geophys. Res. Lett., 36, L14802, doi:10.1029/2009GL038609.

Liu, Z., S. Vavrus, F. He, N. Wen, and Y. Zhong, 2005: Rethinking tropical ocean response to global warming: The enhanced equatorial warming. J. Climate, 18, 4684-4700.

Lu, J., and B. Zhao, 2012: The role of oceanic feedback in the climate response to doubling $\mathrm{CO}_{2}$. J. Climate, 25, 7544-7563.

Ma, J., S.-P. Xie, and Y. Kosaka, 2012: Mechanisms for tropical tropospheric circulation change in response to global warming. J. Climate, 25, 2979-2994.

Manabe, S., and R. J. Stouffer, 1988: Two stable equilibria of a coupled ocean-atmosphere model. J. Climate, 1, 841-866.

Meehl, G. A., and Coauthors, 2007: The WCRP CMIP3 multimodel dataset: A new era in climate change research. Bull. Amer. Meteor. Soc., 88, 1383-1394.

Merrifield, M. A., 2011: A shift in western tropical Pacific sea level trends during the 1990s. J. Climate, 24, 4126-4138.

Neelin, J. D., C. Chou, and H. Su, 2003: Tropical drought regions in global warming and El Niño teleconnections. Geophys. Res. Lett., 30, 2275, doi:10.1029/2003GL018625.

Ringer, M. A., and Coauthors, 2006: Global mean cloud feedbacks in idealized climate change experiments. Geophys. Res. Lett., 33, L07718, doi:10.1029/2005GL025370.

Schneider, T., P. A. O'Gorman, and X. J. Levine, 2010: Water vapor and the dynamics of climate changes. Rev. Geophys., $\mathbf{4 8 ,}$ RG3001, doi:10.1029/2009RG000302.

Seager, R., and Coauthors, 2007: Model projections of an imminent transition to a more arid climate in southwestern North America. Science, 316, 1181-1184.

—, N. Naik, and G. A. Vecchi, 2010: Thermodynamic and dynamic mechanisms for large-scale changes in the hydrological cycle in response to global warming. J. Climate, 23, 4651-4668.

Shin, S. I., and P. D. Sardeshmukh, 2011: Critical influence of the pattern of tropical ocean warming on remote climate trends. Climate Dyn., 36, 1577-1591.

Sobel, A. H., and C. S. Bretherton, 2000: Modeling tropical precipitation in a single column. J. Climate, 13, 4378-4392.

—_, and S. J. Camargo, 2011: Projected future changes in tropical summer climate. J. Climate, 24, 473-487.

- I. M. Held, and C. S. Bretherton, 2002: The ENSO signal in tropical tropospheric temperature. J. Climate, 15, 2702-2706.

Sohn, B. J., and S.-C. Park, 2010: Strengthened tropical circulations in past three decades inferred from water vapor transport. J. Geophys. Res., 115, D15112, doi:10.1029/2009JD013713.

Tanaka, H. L., N. Ishizaki, and A. Kitoh, 2004: Trend and interannual variability of Walker, monsoon, and Hadley circulations defined by velocity potential in the upper troposphere. Tellus, 56A, 250-269.

Tokinaga, H., and S.-P. Xie, 2011: Weakening of the equatorial Atlantic cold tongue over the past six decades. Nat. Geosci., 4, 222-226. 
,-- , A. Timmermann, S. McGregor, T. Ogata, H. Kubota, and Y. M. Okumura, 2012: Regional patterns of tropical IndoPacific climate change: Evidence of the Walker circulation weakening. J. Climate, 25, 1689-1710.

Vecchi, G. A., and B. J. Soden, 2007a: Global warming and the weakening of the tropical circulation. J. Climate, 20, 43164340.

- and - 2007b: Effect of remote sea surface temperature change on tropical cyclone potential intensity. Nature, $\mathbf{4 5 0}$, 1066-1070.

A. T. Wittenberg, I. M. Held, A. Leetmaa, and M. J. Harrison, 2006: Weakening of tropical Pacific atmospheric circulation due to anthropogenic forcing. Nature, 441, 73-76, doi:10.1038/nature04744.

Wentz, F. J., L. Ricciardulli, K. Hilburn, and C. Mears, 2007: How much more rain will global warming bring? Science, 317, 233235.
Xie, S.-P., and S. G. H. Philander, 1994: A coupled oceanatmosphere model of relevance to the ITCZ in the eastern Pacific. Tellus, 46A, 340-350.

— C. C. Deser, G. A. Vecchi, J. Ma, H. Teng, and A. T. Wittenberg, 2010: Global warming pattern formation: Sea surface temperature and rainfall. J. Climate, 23, 966-986.

Zhang, X., and Coauthors, 2007: Detection of human influence on twentieth-century precipitation trends. Nature, 448, 461-465, doi:10.1038/nature06025.

Zhao, M., and I. M. Held, 2012: TC-permitting GCM simulations of hurricane frequency response to sea surface temperature anomalies projected for the late-twenty-first century. J. Climate, 25, 2995-3009.

Zheng, X.-T., S.-P. Xie, G. A. Vecchi, Q. Liu, and J. Hafner, 2010: Indian Ocean dipole response to global warming: Analysis of ocean-atmospheric feedbacks in a coupled model. J. Climate, 23, 1240-1253. 